\title{
INITIAL HUMAN COLONIZATION OF THE AMERICAS: AN OVERVIEW OF THE ISSUES AND THE EVIDENCE
}

\author{
Stuart J Fiedel \\ The Louis Berger Group, 1819 H Street, NW, Suite 900, Washington, DC 20006 USA. Email: sfiedel@earthlink.net.
}

\section{INTRODUCTION}

\section{Out of Asia, But When?}

Ever since José de Acosta's prescient speculation, in 1590, that Native Americans were descended from "savage hunters" who had followed game animals across a land bridge from northeastern Asia into northwestern America (Acosta 1604), most serious scholars have assumed that this was the migration route. The main point of dispute has been the date when the ancestral Asians made the crossing. After many nineteenth-century claims of the discovery of stone tools or bones of "early man" failed to withstand scientific scrutiny, a conservative reaction set in, embodied by the hyperskeptical Aleš Hrdlička of the Smithsonian Institution. Hrdlička dismissed all claims of a human presence in the Americas prior to about 5000 years ago.

However, in 1926, obviously man-made spearpoints were found embedded within the skeletons of extinct giant bison, near Folsom, New Mexico. Prominent scholars viewed the finds in-situ in 1927 and 1928, and verified the coexistence of humans ("Paleoindians") and giant mammals (megafauna) that died out at the end of the Ice Age, then estimated as about 10,000 years ago.

Within the next decade, similar, but not identical points were found alongside the bones of mammoths at Dent, Colorado, and at Blackwater Draw, near Clovis, New Mexico (Cotter 1937). Later investigations at Blackwater Draw in 1949-1950 demonstrated that these points and the associated mammoth skeletons occurred in sediments stratified below the level containing Folsom points (Sellards 1952). Soon, Clovis-like fluted points were being found across the whole of North America, and even in Central America. Junius Bird (1938) excavated points with fishtail-like stems at the southern tip of South America, in apparent association with bones of extinct horses. Very similar stemmed points were later found in Ecuador and Central America. These points appeared to be derivative variants of the Clovis type.

Application of the new radiocarbon dating method in the early 1950 s initially yielded problematic late dates for Folsom, but a date of $10,780 \pm 135 \mathrm{BP}^{1}$ for the Lindenmeier site, published in 1960, appeared valid. In 1959, the Lehner Clovis site was dated at 11,290 \pm 500 and 11,180 $\pm 140 \mathrm{BP}$ (Haury et al. 1959; Haynes 1992). Dates for other sites supported this chronology. It should be noted, however, that Ernst Antevs, based on his climatic-stratigraphic correlations of American sequences with European late glacial chronology, questioned the accuracy of the ${ }^{14} \mathrm{C}$ dates. He preferred a date of $\sim 13,000$ BP for Clovis (Antevs 1935, 1953, 1959).

By the mid-1960s, a coherent picture of initial human colonization seemed to be emerging, as outlined by C Vance Haynes (1964, 1966). Clovis artifacts were made by the first inhabitants of the continent. Their ancestors, hunting people of the northern Eurasian grasslands, had crossed the 1500-km-wide land-bridge, called Beringia, exposed by lowered sea level during the late Pleistocene. However, eastern Beringia (modern Alaska) was sealed off from North America by two massive coalescent ice sheets (the Cordilleran to the west, the Laurentide to the east). The glaciers

\footnotetext{
${ }^{1}$ Here, "BP" refers to uncalibrated conventional radiocarbon age; "cal BP” connotes corrected dates (Fiedel 1999a).
} 
receded as climate warmed toward the end of the Pleistocene, and a passage opened between themthe "ice-free corridor." Ancestral Paleoindians ventured south through the corridor around $11,500 \mathrm{BP}$, stumbling upon a hunters' paradise of naive megaherbivores that had evolved no defensive strategies against human predation. Paul S Martin (1973) seized upon this aspect of the Clovisfirst theory, creating an elegant model that explained both the ubiquitous appearance of fluted spearpoints and the apparently simultaneous demise of numerous species of giant Pleistocene fauna. Martin theorized that Paleoindians had engaged in a killing spree, a blitzkrieg-like rapid advance that resulted in overkill and extinction of the megafauna by $10,000 \mathrm{BP}$.

\section{PRE-CLOVIS SITES?}

A persistent faction of "Early Man" enthusiasts has chafed under the temporal constraints of this Clovis-first model. Claims for ages in excess of 11,500 BP have been advanced for numerous sites, but they have always foundered when the contexts or the often ambiguous artifacts themselves were scrutinized closely (e.g. by Haynes 1974; Waters 1985; Lynch 1990). The continuing absence of verified pre-Clovis sites has been attributed to drastic post-glacial transformation of the landscape, to a generalized and very simple lithic technology that is difficult to recognize, or to a thin and transient early population. Pre-Clovis advocates do not explain why similar factors have not prevented discovery of indisputable Lower and Middle Paleolithic sites in Eurasia. Why are stone flakes made by small-brained early hominins in Ethiopia 2.5 million years ago immediately recognizable as artifacts (Semaw 2000), while supposed >15,000-year-old "tools" from the Americas (e.g. the 50,000year-old quartzite "choppers" from Pedra Furada in eastern Brazil) are indistinguishable from naturally fractured stones (Meltzer et al. 1994)?

At several sites, indubitable lithic artifacts have been found, but their contextual and behavioral associations with early strata or ${ }^{14} \mathrm{C}$-dated organics of pre-Clovis age are ambiguous. Deeply stratified points and blades, associated with bones of extinct fauna, were reported from four locations at Valsequillo in Puebla, Mexico (Irwin-Williams 1967, 1978, 1981). However, the finds became embroiled in controversy when the project geologists, despite the misgivings of the excavator (Irwin-Williams 1981), maintained that the sites were about 250,000 years old (Steen-McIntyre et al. 1981; Szabo et al. 1969). This date proved unacceptable even to the most ardent advocates of preClovis colonization (e.g. Bryan 1978:315). Pichardo (2000) has recently argued for a date of about $15,000 \mathrm{BP}$, based on faunal and stratigraphic correlation.

At Taima-Taima in Venezuela, Bryan et al. (1978) found the midsection of an El Jobo point lying (but not actually embedded) within the pubic cavity of a juvenile mastodon. Unworked pebbles were also present in the cavity, suggesting post-depositional disturbance that could also have brought the midsection into fortuitous association with the fossil. ${ }^{14} \mathrm{C}$ dates of ca. 12,600 to $14,400 \mathrm{BP}$ were obtained for samples of soil organics, bone, and twigs interpreted as the stomach contents of a mastodon. The presence of coal in the vicinity, and permeation of the deposits by groundwater, raised the possibility that the early dates reflected contamination with old carbon (Haynes 1974; Dincauze 1984; Waters 1985; Lynch 1990).

In Bluefish Cave 1, in the northern Yukon, a few stone artifacts-wedge-shaped cores, microblades, and burins - were found in apparent association with remains of mammoth, horse, bison, and other Pleistocene mammals (Morlan and Cinq-Mars 1982; Cinq-Mars and Morlan 1999). ${ }^{14} \mathrm{C}$ dates on the bones ranged between $12,210 \pm 210$ and 25,000 $\mathrm{BP}$. If the dates and association are valid, this would be the oldest cultural material from eastern Beringia. However, it remains uncertain whether the lithic artifacts, typical of the somewhat later Paleoarctic tradition (11,700 BP and later) are dis- 
placed. Supposed bone artifacts in the cave can be reasonably attributed to non-human agency, such as carnivore gnawing (Dixon 1999:61).

At two sites in southeastern Wisconsin, artifacts have been found in association with mammoth bones. At the Schaefer site, a few lithic flakes were found in association with bones directly dated to about 12,300 BP. At the nearby Hebior site, a rather crude biface was found lying within a pile of mammoth bones dated to about 12,500 BP (Overstreet and Stafford 1997). At first glance, the reported finds appear to convincingly demonstrate pre-Clovis human activity, but the behavioral relationship of the artifacts and bones has yet to be clarified and explained.

A lithic assemblage consisting of small blades, flake knives, and a reworked lanceolate point ascribed to the "Miller" type, was recovered from Stratum IIA of Meadowcroft Rockshelter in southwestern Pennsylvania (Adovasio et al. 1990, 1999). Taking the ${ }^{14} \mathrm{C}$ dates at face value, the artifacts from the lower third of Stratum IIA date between 16,205 \pm 975 (SI-2354) and 12,800 \pm 870 (SI-2489) BP. The Miller point, ascribed to middle IIA, is bracketed by the $12,800 \pm 870$ date and a date of $11,300 \pm 700$ (SI-2491) on charcoal from a nearby firepit. Despite frequent assertions that the six dates from lower IIA occur in appropriate stratigraphic order, their actual relative and absolute depths have nowhere been reported. Although the site apparently was painstakingly excavated, detailed plan views and profiles of features and artifact distributions have yet to be published more than 20 years later. The problems here are: 1) the plant remains and the few identifiable animal bones found in Stratum IIA all belong to species found in Holocene deciduous forests (Guilday and Parmalee 1982), not the boreal spruce/pine forest with patches of tundra that prevailed in this region just after the glacial maximum, when the ice sheet lay $80 \mathrm{~km}$ to the north (Mead 1980);2) there is some doubt whether the dated material from IIA was human-created charcoal; samples may have been contaminated by microscopic coal fragments (Tankersley and Munson 1992), by soluble organics in groundwater (Haynes 1980, 1991a), or by non-cultural charcoal churned up by rodents or by Archaic human pit-diggers from the lowest layers of the shelter, where naturally created charcoal lenses yielded dates in excess of 21,000 BP (Kelly 1987); 3) there are no Clovis or early Early Archaic components with diagnostic artifacts, and the ${ }^{14} \mathrm{C}$ dates jump abruptly from 11,300 in middle IIA to $9115 \pm 115$ BP (SI-2061) in the upper third of the stratum - a hiatus of some 3000 calendar years; and 4) the Miller point type, as reconstructed from the Meadowcroft specimen and others collected at the nearby, undated Krajacic site, looks like an Agate Basin variant (Boldurian 1985; Adovasio 1993:212). This suggests an age of about $10,000 \mathrm{BP}$, not $12,800-11,300 \mathrm{BP}$ as indicated by ${ }^{14} \mathrm{C}$ assays .

At Cactus Hill in southeastern Virginia, Archaic assemblages occur in expected stratigraphic order within a ridge of stabilized wind-blown sand. Below them lies a Clovis horizon, with a date of $10,920 \pm 250$ BP. Lying 3-6 inches below the Clovis level is a small assemblage of quartzite blades and bladelets, and three pentagonal, unfluted points made of a metavolcanic stone (McAvoy and McAvoy 1997; McAvoy et al. n.d.; Johnson 1997). Dates of 15,070 \pm 70 (Beta-81590), 16,670 \pm 730 (Beta-97708), and 16,940 \pm 50 (Beta-128330/A) (but also an anomalously late date of $9250 \pm 60 \mathrm{BP}$ [Beta-93899]) have been obtained on charcoal particles from this level. The problematic issues at this site are: 1) If the $\sim 15,000 \mathrm{BP}$ (ca. 17,800 cal BP) date is correct, some 5000 years intervened between the pre-Clovis and Clovis occupations, while only 3 inches of sand accumulated;2) downward drifting of cultural material and animal burrowing are acknowledged problems at the site, and these processes are blamed for the $9250 \mathrm{BP}$ date and several others that seem too recent. The possibility that the dated charcoal represents pre-human, naturally produced material, e.g. from forest fires, cannot yet be excluded. 
Monte Verde, in the lake district of southern Chile, was dramatically promoted from troublesome enigma to putative "paradigm-buster" in 1997 when a small archaeological delegation certified the validity of pre-Clovis evidence there (Meltzer et al. 1997). The small assemblage of indisputable artifacts includes a carefully pressure-flaked, narrow lanceolate point, two similar midsection fragments, a slate rod produced by grinding, and a quartzite biface. If their discovery had not been reported, it is doubtful whether the mélange of organic debris at Monte Verde would have won acceptance as a human habitation site (Fiedel 1999b). Yet, none of the several incompatible site maps in the massive final report (Dillehay 1989, 1997) indicates the find-spots of these artifacts. Three stone scrapers, still mounted in wooden hafts with bitumen, also have been mentioned in various preliminary publications, but only one is briefly described and depicted, and none are mapped, in the final report (Dillehay 1997). Apart from the few well-made, curated lithics, hundreds of supposed tools are merely unmodified but ostensibly utilized broken or rounded river cobbles. Recognizable debitage from lithic flaking - a practically universal marker of Stone Age human encampments-seems, inexplicably, to be absent.

Aside from the lithics, the ostensible evidence of a human presence at Monte Verde consists of a diverse aggregate of organic materials preserved beneath an anoxic peat layer. Dillehay discerned, in a jumble of logs and branches, the quadrilateral foundations of 12 connected rectangular rooms. Tiny fragments of mastodon skin may be remnants of the hut's roof. A separated ovoid "structure" of compacted sand and gravel, about $1 \mathrm{~m}$ in diameter, Dillehay has interpreted variously as a shaman's residence or a mastodon-butchering station. The preserved plant assemblage is dominated by club moss (Lycopodium) spores, totora reed (Scirpus) and bulrushes (Carex), but also includes a few pieces of wild potato skin, various plants that are used medicinally today, and seaweed derived from the Pacific coast, some $30 \mathrm{~km}$ to the west. Some 400 bones, exhibiting minimal modification, represent remains of six mastodon-like proboscideans (gomphotheres). A scapula from an extinct species of guanaco was also found.

These remains on the north bank of Chinchihuapi Creek, known as Monte Verde (MV) II, have been dated to around $12,570 \mathrm{BP}$, on the basis of associated ${ }^{14} \mathrm{C}$ dates on wood, bone, and ivory "artifact" samples that range from around 11,700 to $12,800 \mathrm{BP}$ (ca. 13,400-15,300 cal BP). The overlying peat that sealed and preserved the organic remains immediately after abandonment of the settlement (Dillehay 1989:236; Tuross and Dillehay 1995) dates between 10,300 and 12,000 BP, with four dates in the 11,600-11,800 BP range (Dillehay 1997:43). The most likely age of the supposed human occupation thus appears to be only slightly earlier than the peat, or about 11,800-12,000 BP (ca. $14,000-13,500 \mathrm{cal} \mathrm{BP}$ ).

Dillehay has reported possible evidence of a much earlier human presence at Monte Verde. On the south side of the creek, in a deeper (by $80 \mathrm{~cm}$ ) and older layer, two dozen cracked pebbles of basalt and andesite were found near two ostensible hearths. Carbonized wood from these features dates to about 33,000 BP (possibly ca. 38,000-40,000 cal BP; see Beck et al. 2001). Judging from published illustrations (Collins in Dillehay 1997:462-3), at least one of the stones reportedly found at this MVI locus was certainly chipped by humans. This tool yielded protein residue that may be derived from a mastodon (Tuross and Dillehay 1995) (although no bone or skin was preserved in this locus). If its original position has been accurately reported and post-depositional disturbance can be ruled out, this artifact would offer strong support to an inference of human occupation of MV-I at 33,000 BP. However, Dillehay (1997:774-5) has hesitated to affirm the cultural status and ostensible antiquity of the MV-I material. 
Even setting aside the ambiguous MV-I component, if MV-II is a human encampment, its expedient lithic assemblage (so amorphous that it cannot be termed accurately either a "pebble tool" or "unifacial" industry) is unique, as is its early date. The problems with samples, contexts, and associations, that preclude acceptance of pre-11,500 BP ${ }^{14} \mathrm{C}$ dates from other South American sites (e.g. El Abra, Quirihuac, Muaco, Taima Taima) have been amply discussed by Lynch (1990) (see also Waters 1985).

\section{A REVISED, PRECISE CHRONOLOGY FOR CLOVIS: WHEN, EXACTLY, DID THEY ARRIVE?}

Based on initial ${ }^{14} \mathrm{C}$ results and Pleistocene stratigraphic research, Clovis was usually ascribed an age of around 12,000-11,000 BP. In the early 1980s, averaging of replicate ${ }^{14} \mathrm{C}$ dates on charcoal samples from Paleoindian sites such as Lehner and Murray Springs, resulted in a tighter estimate for the florescence of Clovis culture: 11,200-10,900 BP (Haynes et al. 1984; Haynes 1992). Dates for Folsom sites sometimes overlapped with Clovis dates, in the range of 10,600-11,000 BP; but since the Clovis mammoth kills were stratified below Folsom material at Blackwater Draw, it seemed certain that these cultures were successive, not contemporaneous.

Since the 1970s, archaeologists had realized that fluctuating ratios of ${ }^{14} \mathrm{C}$ and ${ }^{12} \mathrm{C}$ in the past had affected ${ }^{14} \mathrm{C}$ dates significantly, so that ${ }^{14} \mathrm{C}$ ages were about 1000 years too young around $8000 \mathrm{BP}$. Preliminary indications suggested that this difference narrowed in the early Holocene, so Paleoindian specialists were not too concerned about the possible effects of calibration on their chronology. However, recent research has shown that late Pleistocene ${ }^{14} \mathrm{C}$ dates are about 2000 years younger than calendrical ages (for a detailed discussion, see Fiedel 1999a). Clovis-associated dates ranging from 11,300 to $10,700 \mathrm{BP}$ correspond to a short period from about 13,200 to 12,800 cal BP (Taylor et al. 1996) (so it turns out that Antevs's [1953] estimate was correct, after all). The earliest credible Clovis dates of around 11,550-11,600 BP, obtained from the Aubrey site in northern Texas (Ferring 1995, 2001) and the Anzick burial in Montana (Sellars 1999), probably correspond to around 13,400 cal BP (or possibly as early as ca. 13,650 [Friedrich et al. 2001:Figure 7]). However, these few early dates may be misleading outliers. Tom Stafford (personal communication 2002), who ran the Anzick dates, now regards the 11,550 $\pm 60 \mathrm{BP}$ date as erratic, and prefers a date of around 10,700 BP.

For the moment, the limit of precise calibration based on German tree rings (ca. 11,900 cal BP) (Friedrich et al. 1999) falls just short of the era of Paleoindian migrations. Older, "floating" tree-ring sequences of Bølling-Allerød age from Switzerland and Germany may soon be tied securely to the later continuous sequence (Friedrich et al. 2001). Until then, there are several ways to translate ${ }^{14} \mathrm{C}$ dates of 12,000-10,000 BP into "real" calendrical or sidereal years (Table 1). Paired high-precision TIMS U-Th and AMS ${ }^{14} \mathrm{C}$ dates on corals (e.g. Burr et al. 1998) have some utility, but uncertainty about late glacial fluctuations of localized marine reservoir effects limits their reliability. ${ }^{14} \mathrm{C}$ dating of terrestrial macrofossils (e.g. twigs) incorporated within varved lakebed deposits avoids this problem, but uncertainties in this method arise from the possibilities of missing or duplicated varves, vertical displacement of dated samples, and also the evidently peculiar carbon contents of some plant materials (Turney et al. 2000). Furthermore, the varve sequences need to be anchored to some fixed event(s). The ${ }^{14} \mathrm{C}$-dated varves from Lake Suigetsu in Japan (Kitigawa and van der Plicht 1998, 2000) and the varved marine sediments in the Cariaco Basin off Venezuela (Hughen et al. 1998, 2000) both overlap the German dendrochronological record at the recent end, and can be tied to the latter by wiggle-matching the ${ }^{14} \mathrm{C}$ dates. There is, nevertheless, an approximately 100 -calendar-year offset between Cariaco and Suigetsu dates. The Cariaco ${ }^{14} \mathrm{C}$ dates are derived from marine foraminifera embedded in the sediments, and therefore a correction for reservoir effect must be applied. Although the assumption of an invariant local reservoir effect of 420 years throughout the late-glacial is defensible (Hughen et al. 1998, 2000), the possibility of intermittent spikes cannot be precluded. 
Table 1 Comparison of radiocarbon and calendar year dates for deglacial events

\begin{tabular}{|c|c|c|c|c|c|c|}
\hline Climate event & GRIP & GISP2 & $\begin{array}{l}\text { Cariaco } \\
\text { (varves) }\end{array}$ & $\begin{array}{c}\text { Cariaco } \\
\left({ }^{14} \mathrm{C}\right)\end{array}$ & $\begin{array}{c}\text { Central Europe } \\
\text { varves }\end{array}$ & $\begin{array}{c}\text { Central Europe } \\
\text { dendro- }\end{array}$ \\
\hline $\begin{array}{l}\text { YD end } \\
\text { GS-1 }\end{array}$ & 11,550 & 11,645 & 11,565 & 10,050 & 11,535 & 11,570 \\
\hline YD onset & 12,700 & 12,940 & 12,950 & 11,100 & $12,693-12,538$ & \\
\hline GI-1a warming & $12,800-12,700$ & $13,100-12,940$ & $13,100-12,950$ & $11,250-11,100$ & & \\
\hline [LST eruption] & - & - & {$[=13,130]$} & {$[=11,300]$} & 12,836 or 12,880 & $\begin{array}{c}13,130 \\
\left(=11,070{ }^{14} \mathrm{C}\right)\end{array}$ \\
\hline $\begin{array}{l}\text { IACP or GI- } 1 b \\
\text { GI- } 1 \mathrm{c}\end{array}$ & $13,150-12,850$ & $13,250-13,100$ & $13,300-13,100$ & $11,500-11,250$ & $13,214-12,801$ & \\
\hline $\begin{array}{l}\text { OD or GI-1d } \\
\text { GI-1e }\end{array}$ & $14,050-13,900$ & $14,100-14,000$ & $14,100-14,000$ & $12,300-12,100$ & & \\
\hline Bølling onset & 14,700 & 14,700 & 14,700 & 12,550 & & \\
\hline
\end{tabular}

Temporal variations in thickness of the Cariaco varves (the "grey scale") allow correlation with the apparently synchronous fluctuations of oxygen isotope ratios in Greenland ice sheet cores. The rapid onset (cooling) and termination (warming) of the Younger Dryas (YD) climatic episode are crucial marker events for correlation of these records. Both events are clearly recorded as dramatic changes in snow accumulation, temperature, chemical composition, and dust content, in both the GRIP and GISP2 cores from the Greenland ice sheet. Based on counts of annual accumulation layers, the dates for YD termination (the start of the Holocene) are $~ 11,550 \pm 90 \mathrm{cal} \mathrm{BP}$ (GRIP) and 11,645 \pm 200 (GISP2). Unfortunately, there is an unresolved 200-year discrepancy, centered on the 12,500$12,800 \mathrm{cal}$ BP span at the start of the Younger Dryas, between the two cores (Southon 2002). The GISP2 date for YD onset is $12,940 \pm 260 \mathrm{cal}$ BP but the GRIP date is $\sim 12,700 \pm 100 \mathrm{cal} \mathrm{BP}$. The Cariaco date of around 12,950 cal BP supports the GISP2 date.

Lakebed cores in northern Europe and northeastern North America also can be synchronized with the ice core climate records by wiggle-matching fluctuations in oxygen isotope ratios (Schwander et al. 2000; Yu and Eicher n.d.). These lakebed records show that both vegetation (as manifest in the pollen record) and insects responded very rapidly to the Younger Dryas climate changes. In varved lakebed sediments, once the marker of YD onset is recognized, decadal or annual chronological resolution of pollen sequences can be achieved, which renders less precise carbon dating superfluous. It is important to realize, however, that almost all European analysts use the GRIP date of around 12,700 cal BP for YD onset. This can cause problems when lakebed data are combined with INTCAL98 dates, which are based mainly upon the Cariaco varves (Stuiver et al. 1998).

The Lake Suigetsu record, and dated cores from several European lakes, indicate a date reversal or short plateau about 150-200 years before the onset of the Younger Dryas (Goslar et al. 1999:33; Andresen et al. 2000). This event is probably causally related to the brief (ca. 200-year) cold snap within the Allerød called the Gerzensee oscillation or Intra-Allerød Cold Period (IACP). The initial Cariaco Basin report (Hughen et al. 1998) seemed to show the same ${ }^{14} \mathrm{C}$ event at $13,150 \mathrm{cal} \mathrm{BP}$, but the latest decadal sequence reveals no significant break in the ${ }^{14} \mathrm{C}$ dates of around $11,300 \mathrm{BP}$ for this time (Hughen et al. 2000). Nevertheless, the date reversal at 13,200 cal BP (GISP2) also appears in ${ }^{14} \mathrm{C}$ dates from preserved tree stumps of the Bølling-Allerød period at Dättnau, Switzerland. K F Kaiser (1989) has constructed a floating tree-ring chronology for these stumps. Kaiser suggests that an 8-year period of thin rings represents the trees' stunted growth in response to the eruption of the Laacher See volcano in Germany. Tephra from this eruption (LST) serves as a stratigraphic marker (carbon-dated to 11,230 $\pm 40 \mathrm{BP}$ [Hajdas et al. 1995]) within varved lake bed sediments in Central Europe. The thin rings at Dättnau provide a later date for the LST of 11,070 $\pm 60 \mathrm{BP}$, and German 
poplars buried by the tephra have been dated to 10,986 \pm 46 (Baales and Street 1996) and 11,063 \pm $12 \mathrm{BP}$ (Friedrich et al. 1999). ${ }^{14} \mathrm{C}$ dates on Dättnau tree-rings from about 50 years before the LST are in the range of 10,750-10,950 BP (Kaiser n.d.). Varve counts, as well as the Dättnau tree-rings, show that the LST dates from roughly 190 years before the YD onset (i.e. 13,130 cal BP, using the GISP2 date for YD of 12,940; or 12,836 cal BP [Schwander et al. 2000, using a GRIP and varvebased date of 12,693 for YD onset]). For the moment, we are faced with an unexplained discrepancy of about $250{ }^{14} \mathrm{C}$ years between the Cariaco varves (where 13,130 cal $\mathrm{BP}=\sim 11,280$ to $11,300 \pm 50$ $\mathrm{BP}$ ) and the German trees. One possibility is that the oceanic reservoir effect in the Cariaco basin changed significantly between 12,000 and 11,000 BP, so that the standard 420-year correction is not applicable. For comparison, reservoir age in Pacific waters off the coast of British Columbia increased by more than $50 \%$ (from 800 to 1250 years) during the same period (Kovanen and Easterbrook 2002).

How does all this affect Clovis chronology? The most precisely dated Clovis sites are Lehner and Murray Springs, both in Arizona. The ${ }^{14} \mathrm{C}$ date for Lehner, averaged from 12 charcoal assays, is $10,930 \pm 40 \mathrm{BP}$. The date for Murray Springs, averaged from eight assays, is 10,900 $\pm 50 \mathrm{BP}$ (Haynes 1993:221). The most precise of the Lehner dates are 10,950 \pm 90 (SMU-290), 10,940 \pm 100 (A-378), 10,950 \pm 110 (SMU-194), and 10,710 $\pm 90 \mathrm{BP}$ (SMU-340). The most precise date from Murray Springs is 10,840 \pm 70 BP (SMU-41). Based on the latest Cariaco data (Hughen et al. 2000), both sites would fit within a tight calibrated interval $\sim 12,900-12,850$ cal BP. This would put them about 100 years after the Younger Dryas onset. However, the most precise Folsom-associated date is $10,665 \pm 85 \mathrm{BP}$ (SI-3732) from Agate Basin, and the average of six charcoal-derived dates from the Folsom type-site is $10,890 \pm 50 \mathrm{BP}$. The former date calibrates to about 12,820-12,650 cal BP, while the latter is indistinguishable from the Murray Springs date. Thus, if the latest Cariaco calibration (Hughen et al. 2000) is correct for this period, western Clovis would be contemporaneous with Folsom. This conclusion seems dubious on stylistic and stratigraphic grounds, so, pending further elucidation of this interval, I prefer a pre-LST age for Clovis, 13,200 cal BP.

The cause of the Younger Dryas stadial remains to be determined. A popular theory attributes the sudden temperature decline to a breakdown of the ocean's thermohaline circulation system, perhaps caused by Laurentian ice sheet meltwater pouring into the North Atlantic (Broecker et al. 1988). If the ocean surface suddenly became colder, thus absorbing less atmospheric carbon, the same process might account for the peculiar ${ }^{14} \mathrm{C}$ increase that accompanies the YD onset. This increase of ca. 70 per mil is manifest as a jump in dates from about 11,100 to $10,700 \mathrm{BP}$ in a century or less around $12,900 \mathrm{cal} \mathrm{BP}$. After this steep decline, ${ }^{14} \mathrm{C}$ dates within the Younger Dryas form a long plateau with several descending steps: samples dating from $\sim 12,750-12,650$ cal BP yield dates of $\sim 10,600 \mathrm{BP}$; samples dating between $\sim 12,650$ and $12,150 \mathrm{cal} \mathrm{BP}$ produce ${ }^{14} \mathrm{C}$ dates of $\sim 10,400-10,500 \mathrm{BP}$; and ${ }^{14} \mathrm{C}$ dates from the $12,150-11,800 \mathrm{cal}$ BP span are $\sim 10,200-10,300 \mathrm{BP}$. The last section of the plateau extends beyond the YD termination (ca. $11,550 \mathrm{cal} \mathrm{BP}$ ); ${ }^{14} \mathrm{C}$ dates for samples in the interval from 11,800 to 11,250 cal BP are $10,150-10,000 \mathrm{BP}$ (Hughen et al. 2000).

The climatic effects of the Younger Dryas are most evident along the rim of the North Atlantic. As one moves away from this area, the effects become more subtle and may be obscured by lack of resolution and dating problems in pollen cores (Yu 2000; Yu and Wright 2001). It is also likely that regional effects may have been out of phase because of changes in air circulation patterns. The black mats recognized by Haynes (1991b etc.) in the Southwest and southern Plains probably mark the onset of the regional equivalent of the YD (Fiedel 1999a). However, we cannot be sure that they are exactly synchronous with YD onset in the North Atlantic; calibration using the new Cariaco data (Hughen et al. 2000) would imply that the black mats date to about 100-200 years after the isotope 
signature of YD onset in the Greenland ice cores. Clovis artifacts and mammoth skeletons occur just beneath the black mats, but never above them; Folsom points are always within or above the mats. As these features are attributable to increased spring discharge (Quade et al. 2000), they imply a higher water table, increased precipitation, and reduced evaporation, i.e., relatively wet and cold conditions. Globally, however, the YD is characterized as a generally dry period.

Only in the Northeast is there the potential to establish an unambiguous stratigraphic correlation of the YD, sensu strictu as a North Atlantic rim phenomenon, and Paleoindian occupation. The ${ }^{14} \mathrm{C}$ dates of $\sim 10,600 \mathrm{BP}(\sim 12,750 \mathrm{cal} \mathrm{BP})$ from the Debert site (MacDonald 1968) suggest that it was occupied just after the YD onset. Recognition of permafrost effects at the site supports this interpretation. However, Bonnichsen and Will (1999) have raised doubts about dates from Debert and other Paleoindian sites in the Northeast, suggesting that presumed cultural features may actually be treeburns that are unrelated to human activities. They contend that the climatic stress and regional aridity of the YD may have rendered trees more susceptible to fire. This argument seems dubious in the case of Debert, where the clustering of artifacts and charcoal features in "hot spots" (MacDonald 1968 ) is not easily explained away as fortuitous.

A spectacular cache of giant Clovis points at the East Wenatchee site in Washington State lay directly upon sediments that contained particles of Glacier Peak tephra (Mehringer and Foit 1990). Haynes (no date) fancifully speculates that the cache might have been a ritual offering to appease the spirits responsible for the eruption that the Paleoindians had just witnessed. This tephra is widespread in the Northwest and northern Plains. In several lake beds, dates for Glacier Peak tephra layers (actually representing three sequential eruptions- $\mathrm{G}, \mathrm{M}$, and $\mathrm{B}-$ that are chemically indistinguishable) cluster around 11,200 BP (Mehringer et al. 1984; Foit et al. 1993). At Indian Creek, Montana, the tephra date is reported as $11,125 \pm 130 \mathrm{BP}$, and a Clovis occupation stratified above it was dated to $10,980 \pm 150 \mathrm{BP}$ (Davis 2001). It is possible that minute particles of volcanic glass from the Glacier Peak eruptions were aerially transported to Greenland and deposited in the ice. Particles traceable to the eruption of Mount Mazama, another volcano in the Cascade Range, have recently been detected in the annually layered GISP2 core, and allowed precise dating of that event (7627 \pm 150 cal BP) (Zdanowicz et al. 1999). Diagnostic particles from the Laacher See volcano, virtually contemporaneous with Glacier Peak, might also be identified. Barring that, chemical signatures of these events (sulfate peaks) may be identifiable in the ice. Curiously, so far there are no reported signatures of eruptions in the GISP2 core dating between 13,553 and 13,084 cal BP (Zielinski et al. 1996). Finding ice core records of the Laacher See and Glacier Peak eruptions within this interval would accomplish a neat correlation of Old World and New World chronologies.

\section{CLOVIS ORIGINS: ASIA, BUT WHERE EXACTLY?}

Wide (probably premature) acceptance of Monte Verde as a valid pre-Clovis site has thrown Paleoindian studies into disarray, with many calling for new models and even a new "paradigm" in the wake of the perceived collapse of the Clovis-first scenario. If Monte Verde was occupied by hunterforagers before 12,000 BP (ca. 14,100 to 13,500 cal BP), ancestors of this population previously must have traversed either the coast or interior of North America (perhaps decades, perhaps millennia earlier) (Meltzer 1997). However, no proven sites of comparable or greater antiquity have been found in North America, and no similar lithic industry has been identified in any potential Asian ancestral region. Apart from the well-made bifaces, the extreme simplicity of the Monte Verde "tools" is only vaguely reminiscent of the simple flake and core industries of Southeast Asia and Australia. In view of the dissimilarity of Monte Verde and Clovis points, and the absence from the 
MV-II assemblage of formal endscrapers, sidescrapers, gravers, or blades, it is difficult to envision a common ancestral tradition that might have spawned such profoundly different cultures.

For now, I will leave Monte Verde hanging in limbo, due to its unacknowledged or unresolved problems of documentation (the most serious of which still have not been addressed in the new volume of errata [Dillehay 2002]). Nevertheless, if one were to take the ${ }^{14} \mathrm{C}$ dates from Cactus Hill and Meadowcroft at face value, they would indicate that a population with Upper Paleolithic-style biface and blade technology, but lacking fluted points, was present in eastern North America around 15,000 BP (ca. 18,000 cal BP). Such an industry could be termed "proto-Clovis," on the assumption that, with the addition of fluting and a few other distinctive stylistic elements, Clovis could have developed from it (Carlson 1991; Haynes 1987, Fiedel 1999a, 2000). Even if those early dates are rejected as aberrant and implausible, the stratigraphy at Cactus Hill suggests that an assemblage of proto-Clovis aspect may have preceded Clovis by at least a few hundred years. Again, taking dates and association at face value, the artifacts associated with the Wisconsin mammoths imply a human presence around 12,400 BP.

If all of these cases are set aside as ambiguous and still unproven, the logical problem remains of deriving Clovis from some earlier culture. The hypothetical ancestral culture(s?) must be sought in Northeast Asia, Alaska (i.e. eastern Beringia), or somewhere in North America, south of the former glacial front (but, as an American proto-Clovis culture could hardly be autochthonous, one would still be compelled to seek its precursor in the Old World). Recently, Stanford (1998) and Bradley have revived the old idea (e.g. Greenman 1963) that Clovis was derived from the Solutrean culture of Iberia. Apart from other implausible aspects of this theory, temporal discontinuity alone precludes a direct Solutrean-Clovis connection. In western Europe, the Solutrean complex is succeeded by the Magdalenian $\sim 16,500$ BP $(19,000 \mathrm{cal} \mathrm{BP})$, some 6000 years before Clovis appears in North America. The stylistic similarities (e.g. outre-passé flaking) between Paleoindian points and Solutrean bifaces are more credibly attributed to convergence (Straus 2000).

Recent genetic analyses (e.g. Underhill et al. 2000; Ingman et al. 2000) indicate that ancestors of anatomically modern Eurasian Homo sapiens emigrated from Africa about 55,000 years ago and replaced archaic Homo populations. The appearance of Upper Paleolithic toolkits, dominated by blades, generally (but not always) marks the arrival of Homo sapiens. Such blade-dominated assemblages, along with bone tools and ornaments, abruptly replace Levallois-Mousterian industries in southwestern Siberia about 43,000-35,000 BP (Goebel 1993; Goebel and Aksenov 1995), although the Mousterian may have persisted in the Altai mountains to as late as 29,000 BP (Kuzmin and Orlova 1998). If 43,000 BP (ca. 46,000 cal BP?) is the date of entry of Homo sapiens into Northeast Asia, it represents the earliest possible baseline for Paleoindian ancestry.

Both mtDNA and Y-chromosome haplotype distributions in extant human populations point to the region surrounding Lake Baikal as the ancestral homeland of Native Americans (or at least, the last surviving pocket of a once more widespread ancestral Northeast Asian population, subsequently displaced elsewhere in the region). A minor genetic input from the Lower Amur region can also be traced (Karafet et al. 1999; Lell et al. 2002). Almost all Native Americans belong to one of four mtDNA haplogroups (A, B, C, and D), each representing a female descent lineage. A small percentage of Native North Americans belong to a fifth haplogroup, X, which is also present in European and Near Eastern populations and has recently been found in southern Siberian natives (Brown et al. 1998; Derenko et al. 2001). The ubiquitous occurrence of the five haplogroups is probably the result of a single migration by a group initially containing all these Asian-derived haplotypes (Merriwether et al. 1994; Kolman et al. 1996; Malhi et al. 2002). Although the four major Amerind haplogroups are 
widespread in East Asia, only in south-central Siberia (Tuva) and Mongolia do they co-occur and characterize a large percentage of the present population (Derenko et al. 2000; Schurr 2000). Several recent analyses of Y-chromosome structure (Underhill et al. 1996; Bianchi et al. 1997, 1998; Santos et al. 1999) have indicated that all the male descent lineages in the Americas similarly converge toward a single ancestral population. Southern/central Siberia seems to be the area where two ancestral gene pools overlap: one that encompasses the female lineages of America, northern China and Mongolia, and the other, a male lineage that is ultimately related to the ancestors of modern Europeans, and not to East Asian Mongoloids. Perhaps, Paleoindian ancestors emerged as the product of genetic and cultural exchanges around Lake Baikal between proto-Mongoloid natives (mainly females?) and proto-Caucasoids (mainly males?) who carried the Russian Upper Paleolithic complex into the region along with Y haplotype 10 or M45 (Semino et al. 2000) and mtDNA haplotype X.

The ongoing controversy over the racial identity and final disposition of "Kennewick Man," a skeleton from Washington dated to 7900 BP (8900 cal BP) (Chatters 2000), has revived interest in the small number of North and South American skeletons that date from the early Holocene. Some physical anthropologists, abetted by a credulous press (e.g. Rensberger 1997), have indulged in speculation about the supposed relationships of Kennewick Man to Polynesians, and of "Luzia," a ca. 10,500 BP Brazilian, to Australians, Melanesians, or Africans (Neves et al. 1998). In fact, despite all the pre-Clovis hysteria, not much is new. Paleoindians as well as Archaic Indians tended to have longer and more rugged heads than their descendants (Steele and Powell 1992, 1994), a poorly explained tendency that is also well-known in Old World populations (Howells 1967:283). Amerind skulls sometimes display superficial resemblances to other human populations, apart from the classic or specialized Mongoloids of eastern Asia (Howells 1967:296,307). The skeletal record of the latter population is actually very sparse. The earliest known modern sapiens specimens in northern China are still the three individuals from Zhoukoudian. They are probably not much older than 10,000 BP, yet they do not display the typical features of modern Mongoloid peoples (Cunningham and Wescott 2002).

They are an odd group. The male skull strongly suggests the Upper Paleolithic men of Europe. One of the women looks faintly Negroid ('Melanesian' Dr. Weidenreich called her). The other woman looks Eskimolike... Now it is characteristic of Indian populations, with their nondescript cranial form, to give such pale imitations of other racial types.... Actually, this apparently strange assortment in the Upper Cave really looks like a group of American Indians (Howells 1967:307).

It is only around $7000 \mathrm{BP}$ that Chinese Neolithic skeletons appear indisputably Mongoloid (Brown, in press 1999; Kamminga and Wright 1988). Since the ancestors of Paleoindians undoubtedly had left Asia prior to 11,000 BP (13,000 cal BP), we should not expect the earliest people in the Americas to closely resemble the more recent North Asian Mongoloids (Lahr 1995). Like the group responsible for the Zhoukoudian burials, the founding Paleoindian band must already have contained a fair amount of both genetic and phenotypic diversity. Geographic and genetic isolation of far-ranging groups after several generations may have accentuated their pre-existing differences, resulting in the eight distinctive North American cranial types that were recognized by Neumann (1952). Isolation and drift after the rapid expansion, at 13,000 cal BP, of speakers of a presumed ancestral Amerind language (Greenberg 1987; but see Goddard and Campbell 1994) also could have produced the 7 distinct macrophyla that linguists recognize in North America: Uto-Aztecan, Hokan, Penutian, Macro-Siouan, Algonquian, Na-Dene (Athapaskan), and Eskimo-Aleut.

The available genetic data compel us to seek archaeological traces of Paleoindian ancestors in the Trans-Baikal region. Reliable early dates from Upper Paleolithic sites near Lake Baikal and the upper Lena River suggest initial occupation around 37,000 BP, and there are numerous dates of 
23,000-26,000 BP (Kuzmin and Orlova 1998; Kuzmin and Tankersley 1996). The site of Mal'ta, best known for its carved ivory figures of swans and of humans in parka-like clothing, has yielded dates of 20,000 BP on bone samples. About $900 \mathrm{~km}$ to the east, in the Aldan River area of Yakutia, Ust Mil 2 and Ikhine 2 may have been occupied as early as 30,000-35,000 BP, but this dating is suspect (Yi and Clark 1985). A more secure date for initial settlement of this region may be the 18,300 \pm 180 date on wood from Verkhne-Troitskaya; after this isolated date, the next good dates are 15,200 \pm 300 , on charcoal from Avdeikha, and 14,000 \pm 100 , also on charcoal, from Dyuktai Cave, level $7 \mathrm{~b}$. Goebel (1998) suggests that at the glacial maximum, around 18,000 BP (22,000 cal BP), Siberia became so cold that it was virtually uninhabitable, and former residents retreated southward.

Just east of the Aldan sites, the Verkhoyansk Mountains seem to mark an ecological boundary (Hoffecker et al. 1993), which apparently was not breached by western Siberian people until the sudden global warming at $12,500 \mathrm{BP}(14,700 \mathrm{cal} \mathrm{BP})$. Only two sites tentatively dated to about $13,000-$ 11,000 BP are known from this far northeastern section of Siberia (or western Beringia): Berelekh (Mochanov and Fedoseeva 1996a) and Bolshoi Elgakhchan (Kiryak 1996).

The early Siberian Upper Paleolithic toolkits were dominated by macroblades, but it appears that, perhaps as early as 24,000 BP (Kuzmin and Orlova 1998) and certainly by 18,000 BP (Goebel et al. 1991, 2000), microblade-dominated assemblages of the Dyuktai culture (Mochanov and Fedoseeva 1996b) were prevalent all over Northeast Asia. Dyuktai assemblages also typically include wellmade bifaces. The latter are credible prototypes for Paleoindian bifaces, although the Asian points were not fluted. A crudely, probably accidentally fluted point has recently been reported from the site of Uptar in Siberia, but it is a unique specimen in a context that may not be much older than 8300 BP (King and Slobodin 1996). Another striking difference between Dyuktai and Paleoindian assemblages is the absence from the latter of microblades and the small boat- or wedge-shaped cores from which they were struck. Most archaeologists view this distinction as so significant that it would appear to preclude Dyuktai as a candidate for Paleoindian ancestry.

In contrast, the Dyuktai roots of the Paleoarctic tradition or Denali complex of Alaska (eastern Beringia) are universally acknowledged. Paleoarctic lithic assemblages contain the same kinds of microblades and cores as Dyuktai. F H West $(1981,1996)$ has been the foremost proponent of the view that the Paleoarctic tradition gave rise to Clovis (see also Carlson 1991 and Morlan 1991). He is compelled to admit that the complete abandonment of microblade technology by Clovis is a problem, but suggests that a sort of cultural mutation must have occurred, perhaps during the passage through the ice-free corridor.

Critics of West's model have objected that the Paleoarctic tradition is too late to be ancestral to Clovis, because it dates after 10,700 BP in Alaska (Hoffecker et al. 1993:51). They identify the slightly earlier Nenana complex of central Alaska as a more credible Paleoindian ancestor because 1) it seems to be marginally earlier than Clovis, and 2) it contains various tools on blades and flakes, not microblades. However, there is still the small problem of fluted points. Nenana assemblages do include small triangular and teardrop-shaped (Chindadn) points, but these are a far cry from classic Clovis fluted points. It is even possible that Nenana is only a contemporaneous functional variant of Denali, and not a separate culture at all. This possibility is raised by recently reported dates of 11,680 BP for a Nenana-like component with microblades at Swan Point in the Tanana Valley (Holmes 1998). Elsewhere, however, stratigraphic and chronological separation of Nenana assemblages, lacking microblades, from later Denali assemblages is clear. At Dry Creek, for example, a Nenana assemblage (dated 11,120 $\pm 85 \mathrm{BP}$ ) is stratified below a Denali component $(10,690 \pm 250$ BP) (Goebel et al. 1991). The earliest occupation level at Broken Mammoth, about $15 \mathrm{~km}$ west of 
Swan Point, dates to around 11,770 BP (Holmes 1996), and there are two dates of around 11,600 BP from the Mead site, about $1 \mathrm{~km}$ north of Broken Mammoth (Hamilton and Goebel 1999). These ${ }^{14} \mathrm{C}$ dates, associated with rather meager and typologically indeterminate lithic assemblages, push the initial colonization of central Alaska back to around 13,400-13,800 cal BP. Another early Alaskan culture is represented by unfluted, Agate Basin-like points at the Mesa site. Most dates from this site are around 10,000 BP, but one hearth (perhaps a remnant of an earlier Paleoarctic occupation) produced dates of 11,660 \pm 80 and 11,190 $\pm 70 \mathrm{BP}$ on a single split charcoal sample (Kunz and Reanier 1994).

In sharp contrast to Clovis, there is no evidence of mammoth-hunting at any of the early Alaskan sites. Mammoth ivory artifacts are present, both at Broken Mammoth and Swan Point, but in each case, ${ }^{14} \mathrm{C}$ dates have shown the ivory to be centuries earlier than the other material at the site. The inhabitants seem to have been scavenging the tusks of long-dead mammoths as raw material for tools. They were actually hunting elk, bison, sheep, and smaller game, particularly waterfowl, which account for about $40 \%$ of the meat (Yesner 1998a). If mammoths actually had vanished from eastern Beringia before Nenana people arrived (but see Lea 1996), it is reasonable to suppose that the invention of the Clovis point and its related delivery system (bone foreshafts, etc.) resulted from their initial encounter with living mammoths, south of the ice sheets (Pearson 1997).

If we reject the proposition that Clovis mutated, perhaps by a cultural founder effect, from the Dyuktai-Paleoarctic microblade tradition, can Clovis be credibly derived from some other ancestral lithic tradition in Asia? Several authors have looked westward to the Russian Upper Paleolithic. Sites of the Streletskayan complex, dated around 35,000-24,000 BP (Bradley et al. 1995), contain bifacially thinned triangular points and retouched blades that resemble both Nenana and Clovis tools (Haynes 1982; Pearson 1997; Bradley 1997). However, these sites, north of the Black Sea, are thousands of kilometers west of Beringia, and some 14,000 or more years earlier than Clovis. The Mal'ta-Afontova sites of the Lake Baikal and Yenisei regions are eastern outliers of this Russian Upper Paleolithic tradition; at Mal'ta, it may have lasted beyond 15,000 BP. The Ust'-Kova site in the northern Angara region of central Siberia, dated to $23,920 \pm 310 \mathrm{BP}$, contains a blade-dominated industry, with bifaces, that has been compared to Nenana assemblages (Goebel et al. 1991) and also to Clovis (Tankersley et al. 1996).

In view of the oft-remarked similarities of the Zhoukoudian Upper Cave skulls to Amerinds, perhaps we should not exclude northern China from consideration as the Paleoindian homeland. Recent research there has shown that assemblages containing mainly macroblades and leaf-shaped bifaces, along with some microblades, were present at $12,700 \mathrm{BP}$, but that the microlithic element became predominant after 11,600 BP (Elston et al. 1997). Upper Paleolithic emigrants moving north from China (perhaps spurred by competition from the people who made microliths and the earliest ceramics, dated around 13,000 BP in the Amur basin [Kuzmin and Orlova 2000]) might have traveled northeast through the Amur River Basin in the Russian Far East and along the western side of the Sea of Okhotsk before arriving in Kamchatka (this route was the one favored by Chard 1960).

Some Upper Paleolithic assemblages from the Russian Far East (e.g. Ustinovka 1, ca. 16,00010,000 BP [Vasilievsky 1996]) are vaguely similar to Paleoindian toolkits. However, microblades seem to have become part of the regional lithic tradition as early as 24,000-20,000 BP (Derevianko 1989).

The enigmatic Ushki Lake sites of central Kamchatka may have some bearing on this migration scenario. Layer 7, the lowest occupation level at Ushki I, contained stemmed bifacial points, one leafshaped point, burins, end and side scrapers, and stone beads. Notably absent are microblades and 
wedge-shaped cores, which occur in the overlying Layer 6 (Dikov 1996; Dikov and Titov 1984). Dates of 14,300-13,600 BP (ca. 17,000-16,000 cal BP) were obtained for Layer 7, as well as an anomalous date of $9750 \mathrm{BP}$ (Hoffecker et al. 1993). Layer 6, only some $30 \mathrm{~cm}$ above Layer 7, has produced dates of 10,860 to $10,360 \mathrm{BP}(12,900-12,000 \mathrm{cal} \mathrm{BP})$. The ostensibly lengthy hiatus between occupations has raised some doubt about the accuracy of the Layer 7 dates. Indeed, new dates put Layer 7 at $~ 11,300$ BP (Goebel et al. 2002). Although the Ushki assemblage does not look much like Clovis, at least it seems to show that non-microlithic cultures were present in Northeast Asia at the time of Clovis ancestors' emigration.

Based on the meager extant data from Northeast Asia and Beringia, three different origins can be hypothesized for Clovis: 1) Clovis developed around 13,400 cal BP (11,600 BP) from Nenana (Goebel et al. 1991; Yesner 1998b), which in turn had developed from some as yet-unidentified, Ushki-like macroblade tradition of eastern Beringia; 2) Clovis arose by dramatic transformation of an offshoot of the Dyuktai/Paleoarctic tradition, with sudden loss of microblade technology (West 1996); and 3) Earliest Clovis was a distinct culture of northern Alaska, ultimately derived from a Siberian or northern Chinese macroblade/biface tradition, and while perhaps distantly related to both Nenana and Paleoarctic cultures, did not develop from either. Under hypotheses 1) and 2), the differentiation of Clovis from the ancestral cultures would most likely have occurred after emigration southward from Beringia, either during the trek through the ice-free corridor or somewhere in North America, south of the ice sheets. This scenario has the obvious corollary that pre-Clovis or proto-Clovis microblade or Nenana-like assemblages will be found in North America-something like Cactus Hill, perhaps. Under the third hypothesis, earliest Clovis sites would be found in Alaska, and Clovis would appear full-blown, without local antecedents, south of the glaciers.

Unfortunately, the small fluted points found in northern Alaska, on the surface or in shallow mixed contexts, cannot be dated (Clark and Clark 1983; Reanier 1995; Hamilton and Goebel 1999). They are usually considered to represent a northward reflux of relatively late (ca. 10,500 BP?) Paleoindians from the northern Plains (Clark 1991; Dixon 1999:181-9). However, the multiple fluting and inverted-v-shaped basal concavities that characterize the Alaskan points are diagnostic of neither the Folsom nor Goshen point-making traditions that prevailed in the northern Plains from around 10,900 to 10,000 BP. These attributes occur instead in California and Mid-Atlantic fluted points (Anderson and Faught 1998) that may be relatively early; multiple flutes also occur on Clovis-like points from Guatemala and Chile (Lynch 1983:97,104). It is unclear why any late Paleoindian hunters would have been drawn back to the far north during the Younger Dryas; bison, their preferred prey, did not migrate north. A southern Paleoindian migration into Alaska would have been difficult at 10,500 BP, because these immigrants would have confronted expanding Paleoarctic Denali populations. As an alternative to the dominant view, the geographic segregation of fluted point finds in northern Alaska from the Nenana sites in central Alaska, might be interpreted as indicating two contemporaneous but distinct cultures $\sim 11,600 \mathrm{BP}(13,400 \mathrm{cal} \mathrm{BP})$. If dubious identifications of mammoth residues on Alaskan points could be confirmed (Loy and Dixon 1998), the case for a northern Alaskan (or eastern Beringian) emergence of basic Clovis lifeways would be strengthened.

On the assumption that ancestral Paleoindians from Alaska passed through a widening ice-free corridor $\sim 11,600 \mathrm{BP}$ (ca. 13,400 cal BP), we might expect to find proto-Clovis or earliest Clovis sites at the southern end of the corridor, in the northern Plains. Although there are many stray fluted point finds from Alberta (Ives et al. 1993), including a "stubby" type that is a plausible transitional form from Nenana triangular points, only one point has been found in a datable context in western Canada. This small fluted (or basally thinned) point from Charlie Lake Cave, British Columbia, was in a level that yielded three dates on bison bone collagen: 10,770 $\pm 120,10,450 \pm 150$, and 10,380 \pm 
160 BP (Fladmark et al. 1988). While these dates suggest a probable Younger Dryas age for the occupation, as they are collagen-derived they might actually be too young. A Clovis-era age is thus not excluded (recall that some Clovis sites, including the Anzick child burial, have yielded ca. 10,700 BP dates!).

A proto-Clovis assemblage might look like the material from Cactus Hill, with its unfluted points, small blades, and conical cores (McAvoy and McAvoy 1997). Bladelets also occur in a probably early Clovis assemblage at the Big Pine Tree site in South Carolina (Goodyear 1997), and in Stratum IIA at Meadowcroft Rockshelter. Or, Clovis precursors might have produced the artifacts found at Santa Isabel Iztapan, near Mexico City, in the early 1950s (Aveleyra 1956). Both an unfluted lanceolate point and a bipointed laurel leaf or Lerma-like point were found there among the bones of a single mammoth. This faunal association strongly suggests a pre-Younger Dryas age, although the ${ }^{14} \mathrm{C}$ date reported in the 1950s was only $~ 9250$ BP (MacNeish 1983). The lanceolate is a plausible prototype for Clovis (Haynes 1987), while the laurel leaf form, made by the same band of hunters, could be ancestral to the El Jobo points of South America (Pichardo 2000).

A few dates from other areas hint at a human presence around 12,000 BP (ca. 13,500-14,000 cal BP). In Florida, a wooden stake inserted, perhaps by human action, into a tortoise shell in the Little Salt Spring sinkhole, yielded a date of 12,030 $\pm 200 \mathrm{BP}$ (but the shell itself is much older, 13,450 \pm 190 BP) (Clausen et al. 1979:611). Several dates for Zone D of the Page-Ladson site, which contained an ostensibly incised mastodon tusk, ranged from 13,130 \pm 200 to 11,770 \pm 90 BP (Faught 1996:162). In the absence of a definitely associated lithic industry, the affiliations of this dimly perceived occupation remain obscure.

Similarly, the early dates of 11,840 $\pm 130,11,700 \pm 95$, and 11,450 $\pm 110 \mathrm{BP}$, reported for the "preFolsom" level at Agate Basin in Wyoming (Haynes et al. 1984) cannot yet be tied to early Clovis or to any other culture. It should be noted that dates associated with unfluted lanceolate Goshen points in the northern Plains range from about 10,200 BP (Donohue 1998) as far back as 11,570 $\pm 170 \mathrm{BP}$ (Frison 1991, 1993, 1996) or 13,400 cal BP. If the earlier dates are not erroneous (lignite contamination is suspected at the Mill Iron site) Goshen might be ancestral to Clovis, or else some still earlier common ancestral culture, without fluted points, remains to be found.

Several groups of diverse Beringian ancestry may have undertaken exploratory forays throughout North and South America after 14,700 cal BP. However, in the period of climatic oscillation after $\sim 13,400$ cal BP (11,500 BP), the people who made Clovis points and associated tools perhaps enjoyed a unique technological/adaptive advantage (as efficient mammoth-killers?) over any potential competitors, and rapidly expanded their range throughout North America. In Central America, stylistic drift resulted in emergence of the fishtail point variant (probably derived from southeastern Clovis) (Morrow and Morrow 1999; Pearson 1998). People who made fishtail points reached Tierra del Fuego by about 13,000 cal BP. If they encountered a precursor population of the El Jobo complex in South America (which still seems improbable), they either absorbed or replaced them. Continuing stylistic drift and isolation, coupled with rapid adaptation to diverse and changing terminal Pleistocene environments, probably resulted in emergence of distinctive regional styles (e.g. Monte Alegre in Brazil, Paijanense in coastal Peru, Dalton in the southern Midwest, etc.) by 12,500 cal BP.

\section{MIGRATION ROUTES: COAST OR INTERIOR?}

The first successful human colonization of Beringia probably occurred soon after the onset of the Bølling-Allerød period (14,700 cal BP, ca. 12,500-12,900 BP), when temperatures rose abruptly in the northern hemisphere. By 12,500 BP, summers in Beringia were as warm as they are today (Elias 
2000). Rising temperatures and increased insolation caused rapid retreat and melting of the great ice sheets. Although the late Pleistocene geology of western Canada is still somewhat debatable, there is a consensus that the Laurentide and Cordilleran glaciers had coalesced during the Last Glacial Maximum (22,000-19,000 cal BP). The Cordilleran glacier already was shrinking along its western margin at 13,300 BP (ca. 16,000 cal BP) (Cowan and Bornhold 1998). The Laurentide ice sheet suffered catastrophic ablation around $12,500 \mathrm{BP}$, causing a global meltwater pulse (MWP IA) in the ocean (Fairbanks et al. 1992; Sowers and Bender 1995). In the southern Pacific, MWP IA is manifest as a rapid 16-meter rise in sea level between 14,600 and 14,300 cal BP (Hanebuth et al. 2000). As the ice sheets receded, an "ice-free" corridor opened between them, filled with meltwater lakes. ${ }^{14} \mathrm{C}$ dates from these lakes are often unreliable, due to hardwater effects and bulk samples. In any case, it seems a safe assumption that a corridor was open soon after the documented Laurentide ablation, around 12,500 BP, and revegetation of the barren landscape was probably rapid. A vegetative cover of herbs, grasses, sedges, mosses, and algae is reconstructed for the southern end of the corridor at 12,000-11,700 BP (Ives et al. 1993). Mammoth, horse, camel, elk, and musk-ox bones occur in late Pleistocene terraces of the Peace River valley in Alberta, leading Fladmark et al. (1988:382) to conclude that "the later stages of the ice-free corridor clearly were not inhospitable."

The ice-free corridor has long been regarded as the most likely route of Paleoindian entry into North America. Despite recent advocacy of an alternative coastal migration route (Fladmark 1979, 1983; Gruhn 1988, 1994; Fedje et al. 1996; Josenhans et al. 1997; Mandryk 1998; Dixon 1999, Fedje and Josenhans 2000) the corridor remains a viable option (Jackson and Duk-Rodkin 1996; Ives et al. 1993; Wilson and Burns 1999).

Advocates of a coastal migration (e.g. Dixon 1999:249) often cite Monte Verde (Dillehay 1997). However, if it really is a human habitation site (see Fiedel 1999b for a skeptical assessment), Monte Verde offers no evidence of a marine orientation. It sits beside a creek, some 20 miles from the Pacific shore. The faunal assemblage includes no fish or marine shellfish (Dillehay 1997:674). Only the presence of seaweed suggests that the inhabitants ever visited the shore. Not the subsistence pattern, but only the early date of Monte Verde (ca. 12,500-12,000 BP) might imply a coastal route, because it leaves so little time for a long overland journey from a just-opened and inhospitable corridor almost to the tip of South America. Furthermore, the absence of any similar sites of comparable antiquity in North America can be conveniently explained by supposing a journey by boat that left no traces on the land.

Without a pressing need to account for the chronological and cultural anomaly of Monte Verde, the search for a coastal migration route loses its urgency. Granted, recent research suggests that the coast of western Canada may have offered migrants a more attractive landscape than the ice-free corridor. Coastal ice had receded from most areas of British Columbia and Alaska by 14,000 BP (ca. 16,500 cal BP), and these areas were vegetated by 13,000 BP (Josenhans et al. 1997). Drowned Late Pleistocene coastal landscapes have been recognized at a depth of more than $150 \mathrm{~m}$ in the waters off the Queen Charlotte Islands, and a single basalt flake, estimated to date to ca. 10,200 BP, was recently dredged up from this context (Fedje and Josenhans 2000). Bears were living on Prince of Wales Island by 12,300 BP (Heaton et al. 1996). If these omnivores could thrive on the coast, so too, perhaps, could people. But, mere potential for habitation is one thing, archaeological demonstration is something else entirely. Despite years of contracted and academic survey work, neither the Northwest nor California coast has yet produced a single credible pre-Clovis site. Coastal route advocates lament that Holocene sea-level rise has drowned the evidence that would prove their case. However, there are elevated headlands along the Alaska coast that would have been habitable in the late Pleistocene (Yesner 1998a), and on the coast of mainland British Columbia, some near-coastal Pleis- 
tocene areas now sit more than $200 \mathrm{~m}$ above the present sea level, because of isostatic postglacial uplift (Josenhans et al. 1997:74). No early sites have yet been identified in these areas. In any case, as Meighan (1983) and Dillehay and Meltzer (1991:291) observe, even if the littoral-focused sites of coastal foragers are now underwater, their subsistence-settlement system probably also had an interior aspect, which should be archaeologically recoverable.

The earliest known lithic industries on the North Pacific coast are no older than 9800 BP (about $11,200 \mathrm{cal} \mathrm{BP}$, or 2,000 years later than Clovis). Lithic assemblages in the Alexander Archipelago in southeast Alaska date to 9500-9000 BP (Ackerman 1992). In Gwaii Haanas, off the British Columbia coast, the earliest microblades and bifaces date to about 9400 BP (Fedje et al. 1996). On Prince of Wales Island, the same cave (49-PET-408) that yielded 12,300 BP bear bones contained human bones, but the latter date only to around $9800 \mathrm{BP}$ (or ca. $9200 \mathrm{BP}$, corrected for marine reservoir effect [Dixon 1999:118]). At Namu, on the central British Columbia coast, an assemblage of unifacial pebble tools, leaf-shaped, unstemmed bifaces, scrapers, and gravers, dates from $9720 \pm$ $140 \mathrm{BP}$ (Carlson 1998). In western Oregon, the earliest site near the coast (50 km inland) dates to barely $9000 \mathrm{BP}$.

In California, numerous claims of great antiquity for both alleged stone tools (e.g. Calico Hills) and for human skeletal remains (e.g. Sunnyvale, Del Mar, Yuha), have been effectively refuted (e.g. Meighan 1983; Stanford 1983; Taylor et al. 1985; Taylor 1991:90). In fact, there is now no unambiguous evidence of pre-Clovis people in coastal (nor interior) California. Although numerous Clovis points have been found on the surface at California interior sites (e.g. Borax Lake), only a few isolated fluted points have turned up near the coast (Erlandson 1994). Excavations at Daisy Cave on San Miguel Island (Erlandson and Moss 1996, Erlandson et al. 1996, Erlandson 1998) show that the Channel Islands off southern California were occupied by 10,400 BP. New ${ }^{14} \mathrm{C}$ dates of $\sim 11,000 \mathrm{BP}$ have been obtained for Arlington Springs Woman, a partial skeleton excavated in the 1960s on nearby Santa Rosa Island (Wisner 1999; Stafford et al. 2002). This makes her a possible Clovis contemporary, but not a predecessor. Claims of association on Santa Rosa Island of ostensible artifacts and hearths with bones of pygmy mammoths, dated around 40,000-12,000 BP (Orr 1968), have not withstood close scrutiny (Stanford 1983:71; Waters 1985:132; Cushing et al. 1986). The first nearly intact skeleton of a pygmy mammoth was found on the island in 1994. It is a very aged individual, who seems to have died naturally and was not dismembered or butchered by humans. A ${ }^{14} \mathrm{C}$ date of about 12,840 BP has been reported (Agenbroad et al. 1995). A renewed effort to date other pygmy mammoths might yield interesting results, as a test of the coastal hypothesis. Island fauna are generally hunted to extinction soon after humans arrive (e.g. moas in New Zealand [Holdaway and Jacomb 2000]). The age of the last pygmy mammoth should tell us when humans first occupied the coast of southern California (Johnson 1983:513; Meighan 1983:450). A pygmy mammoth vertebra recently has been dated to $\sim 11,030 \mathrm{BP}$ (Agenbroad 2002).

Two sites found recently in southern Peru, which offer clear evidence of surprisingly early intensive use of marine resources, have been cited in support of a coastal migration model. At Quebrada Tacahuay, a hearth dated to around 10,530-10,770 BP (ca. 12,300-12,850 cal BP) was associated with bones of cormorants, other birds, anchovies, and sea mammals (Keefer et al. 1998; deFrance et al. 2001). Quebrada Jaguay 280, located $220 \mathrm{~km}$ to the north, is of similar antiquity; the lowest level yielded dates of 11,088 \pm 120 and 11,105 $\pm 260 \mathrm{BP}$, and the overlying layer dates to $\sim 10,700 \mathrm{BP}$ (Sandweiss et al. 1998, 2000). The dated levels contained remains of drumfish and clams. At Quebrada Jaguay 280, obsidian was found, that can be traced to a source in the Andes, $130 \mathrm{~km}$ inland. It was probably acquired there during the interior phase of a seasonal round that included terrestrial hunting as well as periodic visits to the shore. Comparably early dates of $\sim 11,000 \mathrm{BP}$ have been 
obtained from Fell I or fishtail point occupations in Patagonia and the Pampas of Argentina (Nami 1996, Flegenheimer and Zarate 1997), where hunting of horses and other Pleistocene fauna is attested. The Peruvian sites probably represent, not waterborne coastal migrants, but an early stage of coastal adaptation by groups previously committed, like their contemporaries in Patagonia and Chile (e.g. at Tagua Tagua [Nunez and Santoro 1990]), to terrestrial hunting and gathering.

\section{THE OVERKILL HYPOTHESIS: DID PALEOINDIAN HUNTING FINISH OFF THE MEGAFAUNA?}

More than 30 genera of large-bodied mammals (megafauna) in the Americas became extinct around $11,000 \mathrm{BP}(13,000 \mathrm{cal} \mathrm{BP})$. These animals had thrived in the sustained warm climate of the last interglacial, and had survived many sudden temperature changes (18 warm Dansgaard-Oeschger interstadials and six cold Heinrich events) during the Wisconsin glaciation, after around 70,000 cal BP. The warm-cold oscillations that marked the final stages of the Pleistocene between around 17,000 and $11,500 \mathrm{cal} \mathrm{BP}$ were not markedly more severe than the earlier temperature spikes. The only obvious difference about this deglacial period was the arrival of humans at 13,500 cal BP. Martin (1973) theorized that Paleoindian hunters, radiating rapidly through the continent in a sort of "blitzkrieg" movement, slaughtered the unwitting megafauna in a few centuries. Martin's critics have wondered why, of all the species that disappeared, only a few (mammoth, mastodon, possibly horse, sloth, and camel) are actually represented by skeletal remains at Paleoindian kill or campsites. On the other hand, Paleoindians clearly did hunt bison and caribou, both of which survived the extinction episode. Critics of the overkill hypothesis also note that a number of bird species died out, which would be difficult to attribute directly to human predation (Grayson 1991). Some have suggested that the ostensible suddenness of the extinction was illusory, that the die-off may have occurred gradually over millennia (Meltzer and Mead 1985). However, recent AMS dates on bone reaffirm that extinction of all megafauna occurred abruptly between 11,400 and 10,800 BP (13,000 cal BP) (Graham 1998; Graham et al. 2002). These dates equate to the onset of the Younger Dryas cold episode. In numerous exposed stratigraphic profiles in the Southwest, a thin aquoll or "black mat" (spring-laid soil) directly overlies the bones of the last mammoths. The black mats appear to represent a regional pluvial period, with increased spring discharge, at the onset of the Younger Dryas (Haynes 1998 and undated; Quade et al. 1998).

Alternative, environmental explanations of the great extinction rely on the sharp contrasts between late Pleistocene and Holocene conditions, such as reduced patchiness of vegetation zones and more extreme seasonal variation (e.g. Graham 1998). The obvious problem with such models is that, in North America, the megafaunal extinction occurred at the onset of the Younger Dryas $(13,000 \mathrm{cal}$ BP), 1500 years before the rapid warming that marked the start of the Holocene $(11,570 \mathrm{cal} \mathrm{BP})$. In southern South America, deglacial warming began about 17,000 cal BP (14,000 BP), and the environment seems to have approached essentially modern conditions by $12,500 \mathrm{BP}(14,500 \mathrm{cal} \mathrm{BP})$. Yet, Paleoindian hunters were killing horses in Patagonia around 12,900-12,200 cal BP (Alberdi et al. 2001; Nami 1996), while ground sloths were still living there (Long and Martin 1974; Long et al. 1998). Thus, it seems that the South American megafauna might have survived regional warming and environmental change, had they not suffered predation pressure from humans.

The overkill theory for American extinction has been strengthened by re-analyses of analogous cases. In Australia, the arrival of humans around 50,000 cal BP was soon followed by the extinction of giant birds and marsupial megafauna, around 46,000 cal BP (Flannery 1999; Miller et al. 1999; Turney et al. 2001; Roberts et al. 2001). In New Zealand, in the late 13th century, several species of moa, with an estimated population of 158,000 birds, appear to have been wiped out by the first Maori settlers in about 50-160 years (Holdaway and Jacomb 2000). 
However, the overkill theory is confounded by an odd paradox in Beringia. On the one hand, it seems that mammoth had disappeared from eastern Beringia at least several hundred years before initial occupation by Nenana foragers. On the other hand, on Wrangel Island, which would have been in north-central Beringia before the ocean waters rose, dwarf mammoths seem to have persisted until $3700 \mathrm{BP}$ (Vartanyan et al. 1995). While their survival suggests that climate change alone was not enough to cause extinction, it also raises the question, how could efficient proto-Paleoindian hunters have missed this pocket of vulnerable megafauna en route to America?

\section{RAPID INITIAL COLONIZATION: WHY AND HOW DID THEY GO SO FAR, SO FAST?}

Clovis expansion across the whole of North America was almost incredibly rapid. The earliest relatively precise charcoal-based ${ }^{14} \mathrm{C}$ dates yet obtained for North American Clovis are two dates of around 11,550 BP (about 13,300-13,400 cal BP) for the Aubrey site in Texas (Ferring 1995, 2001). The oldest of the amino-acid-based dates for the child buried with a Clovis tool cache at Anzick, Montana, is 11,550 \pm 60 (CAMS-35912) (Sellars 1999). However, dates for most western Clovis sites cluster around 10,900 BP. New AMS dates from the Clovis stratum at Shawnee-Minisink in eastern Pennsylvania (10,940 \pm 90 [Beta-101935] and 10,900 \pm 40 BP [Beta-127162]) (Dent 1999) show that Eastern Clovis is as old as the classic southwestern sites.

The fishtail (or Fell 1) points found in Central America (Snarskis 1979; Ranere and Cooke 1991; Ranere 1997; Pearson 1998), Ecuador (Mayer-Oakes 1984), Chile (Núñez and Santoro 1990), Patagonia (Bird 1938, Nami 1996), and the Pampas (Flegenheimer 1986/1987) are clearly derived, with slight stylistic modification, from North American Clovis (Lynch 1983; Morrow and Morrow 1999). Fell 1 fishtail points in the Southern Cone have been securely dated at $10,300-11,100$ BP or approximately 12,300-13,000 cal BP (e.g. at Cueva del Medio in Patagonia [Nami 1996] and at Cerro La China and Cerro El Sombrero in the Pampas [Flegenheimer 1986/1987; Flegenheimer and Zarate 1997]). Several ostensibly older dates of around 13,000-12,000 BP have also been reported for Los Toldos 3, Level 11 (12,600 \pm 600 ); Cueva del Lago Sofia (11,570 \pm 60 and 12,990 \pm 241$)$; and Piedra Museo (ca. 12,700) (Politis 1997), but all these dates seem to be erratic, as associated assemblages are either clearly Fell I or are probable functional variants that lack the diagnostic points (Nami 1994). Recently reported AMS dates for these sites imply that all dates older than 11,300 BP are in fact erratic outliers (Steele et al. 2001).

Thus, the interval separating the initial inhabitants of the Southern Cone from the earliest Clovis hunters in Texas is probably only 400 years $(13,400-13,000 \mathrm{cal} \mathrm{BP})$. At a reasonable pace of $24 \mathrm{~km}$ per day, it would have taken Clovis ancestors 80 days to walk $1900 \mathrm{~km}$ through the ice-free corridor. To get from the southern end of the corridor to Texas by the most direct route, they would have covered about $2100 \mathrm{~km}$, perhaps in a matter of months or a few years (Haynes, undated). If the initial Clovis-descended colonists, setting out from Panama, moved at a comparable rate on an essentially linear route of around $6400 \mathrm{~km}$ along the Andean chain, they would have reached Tierra del Fuego in much less than 400 years, as required by the chronological evidence.

Such rapid travel across vast distances is clearly feasible, even if the motivation behind it is debatable. More difficult to envision and accept is the rate of demographic increase that must be postulated to fill up the American continents in four centuries. At a density characteristic of recent Subarctic hunting peoples, 1 person per $200 \mathrm{~km}^{2}$, the Paleoindian population would have had to reach about 125,000 to accomplish this. Starting from a pioneering band of 50, this number would have been attained in about 300 years, assuming exponential growth and 25 years per generation. But, is such rapid growth (each couple rearing, on average, four children to adulthood) possible while main- 
taining high mobility? Modeling by Surovell (2000) indicates that it is indeed feasible. Beaton (1991), Anderson (1995), and MacDonald (1998) suggest plausible social mechanisms by which Paleoindian mating networks could have assured their reproductive success.

The most obvious, and traditionally assumed, motivation for far-ranging Paleoindian movements is a commitment to hunting of migrating herds of big game. However, it has become fashionable to question the supposedly "macho" image that was evoked initially by repeated associations of Clovis points with mammoth skeletons. A more generalized foraging strategy is now often assumed, punctuated by rare episodes of megafauna-hunting. However, total rejection of the traditional model seems unwise. Paleoindians, descended from the Upper Paleolithic hunters of northern Eurasia and Beringia, had a long tradition of primary dependence on meat. Plant foods were simply insufficient to support human life in Arctic and Sub-Arctic latitudes. Furthermore, a colonizing population could rely on pre-existing knowledge of the behavior of large, far-ranging mammals, while it would have taken years to acquire intimate knowledge of the distribution and uses of territorially restricted and variable plant species. Because of rapidly changing environments, late Pleistocene fauna probably often shifted their ranges and density. These changes would have prevented Paleoindians from settling in at a particular location and predicting the scheduled movements of their prey. Thus, hunting of megafauna and frequent movement would have been elements of a successful adaptation for early Paleoindians (Kelly and Todd 1988).

As the Paleoindians moved southward into temperate deciduous forests, then into equatorial montane forests and even rainforests, many more potential plant foods would have become accessible, while the density of megafauna diminished. Consumption of fish and berries is attested at the Shawnee-Minisink site (McNett 1985). Bison and deer are reported from Aubrey, but so is turtle; it is as yet unclear whether bones of small mammals, fish, and birds in pond sediments represent a cultural or natural deposit (Ferring 1995, 2001). Whatever the precise balance of large and small game in Clovis subsistence, the collapse of megafaunal populations at 13,000 cal BP (11,000 BP) compelled Paleoindians everywhere to adopt more broad-spectrum diets. Evidence has been accumulating in South America of a rapid change in subsistence after 11,000 BP. Roosevelt et al. (1996) present evidence of intensive consumption of tree fruits, along with fish, birds, mollusks, reptiles, amphibians, small- and medium-sized mammals, in the Monte Alegre culture in the Brazilian Amazon, by around 10,600 BP. Basal layers of several central Brazilian rockshelters also indicate broad-spectrum use of fruits, roots, and small game starting between 11,000 and 10,500 BP (Kipnis 1998; Prous and Fogaça 1999). Some sites in this region have produced even older dates, e.g. Lapa do Boquete (three dates ca. 12,000 BP, and two ca. 11,440 BP), Santana do Riacho (11,960 \pm 250 BP), and Sitio do Meio (two dates ca. 12,300 BP). It seems likely that these ostensibly pre-Clovis dates are misleading outliers, like the Southern Cone dates older than 11,300 BP (Steele et al. 2001). The contemporaneous appearance of a marine adaptation in coastal Peru between 11,000 and 10,700 BP has already been noted. Hunting peoples can quickly and radically alter their subsistence modes. In an analogous case, Thule whale-hunters abandoned whaling and became reliant on fishing, sealing, and caribou-hunting within 200 years after their initial rapid colonization of the Canadian Arctic (McGhee 1984; Fiedel 1998; Whitridge 2001). Evidence of broad-spectrum economies, even as early as $11,000 \mathrm{BP}$, is not incompatible with initial migration a few hundred years earlier.

The known distribution of fluted points (Anderson and Faught 1998, 2000) shows no obvious relationship to environmental parameters, as the concentrations encompass several distinct vegetation zones. Thus, it does not appear that Paleoindians were searching for any particular preferred habitat. Perhaps, Haynes's "Clovis drought" (probably corresponding to the warm spike at the end of the Allerød, ca. 13,100 cal BP) caused fragmentation of mammoth herds into oasis-like refugia around 
remnant lakes. A leap-frogging strategy (Anderson and Faught 1998; Anthony 1990; Fiedel and Anthony 1979), rapidly covering long distances from one refugium to the next, might have been most efficient way for Clovis hunters to encounter their preferred prey (G Haynes 1999). There may be a processual similarity in the island-hopping of the early Polynesian Lapita people, the movement of Linearbandkeramik people between patches of arable soil in Central Europe, and Clovis migration between dispersed mammoth refugia, which would explain the seemingly explosive character of each of these population movements.

\section{WHAT CAN RADIOCARBON DATING CONTRIBUTE TO PALEOINDIAN STUDIES?}

Archaeologists, of course, can always use more Paleoindian sites, particularly undisturbed sites with intact stratigraphy, discrete features and activity areas and datable charcoal. Important recently discovered sites include Aubrey and Gault in Texas, Big Eddy in Missouri (Ray et al. 1998), and Carson-Conn-Short (Broster and Norton 1996) in Tennessee. We may hope that more such sites will be found in Siberia, Alaska, the ice-free corridor, and the west coast. Whatever turns up in the future, for now, more judicious and rigorous application of ${ }^{14} \mathrm{C}$ and ancillary chronometric techniques to the existing data base can clarify the chronology and processes of Amerindian migration.

The development of AMS dating in the 1980s has introduced much greater precision when dealing with small samples. Its effect is clearly seen in the case of the Shawnee-Minisink site in Pennsylvania. Conventional dates run in the 1970s, with sigmas ranging from 300 to 1000 years, had suggested an age of about 10,600 BP. Fortunately, some carbonized hawthorn plum seeds from a hearth had been saved, and recently run AMS dates put the Clovis occupation at about 10,900-10,950 BP, coeval with classic southwestern Clovis sites such as Lehner and Murray Springs. Unfortunately, technical innovations do not offer a panacea for problems of degraded, dislocated, or contaminated samples. All too often, dates from Northeastern Paleoindian sites come out too young to be credible. Is the seemingly more recent charcoal derived from trees that grew and burned on these sites millennia after human occupation? In other cases (Meadowcroft, Cactus Hill), the dates seem too old to be accepted without hesitation.

Tom Stafford's recent development of protocols for dating purified amino acids from bone allows direct dating of late Pleistocene faunal and human remains (Stafford 1994), with a precision of \pm 60 years. Preliminary reports of the faunal dating project undertaken by Stafford, Graham, and Semken (e.g. Graham 1998; Graham et al. 2002) indicate that terminal Pleistocene extinction was rapid indeed. Final dates for 17 megafauna species cluster between 11,400 and 10,800 BP. Although Graham has suggested, based on dates of around 10,800 BP, that the proboscideans were the last to go, we should recall that dates of 10,800 have also been obtained for Clovis sites that appear to be of late Allerød age. Furthermore, because of the rapid increase in ${ }^{14} \mathrm{C}$ at the Younger Dryas onset, dates drop from about 11,200 to 10,800 BP in about a century of real time (Hughen et al. 2000). The apparent precision of the new bone dates is not always definitive. Consider, for example, the range of reported dates for the Anzick child burial, which was associated with a spectacular Clovis artifact cache. Should we put greatest reliance on a date of 10,240 $\pm 120,10,710 \pm 100,10,940 \pm 90$, or $11,550 \pm 60 \mathrm{BP}$ ? Haynes (personal communication) generally takes the oldest of any series of bone dates as the most credible.

Poor survival of charcoal, bone, and other organic materials of terminal Pleistocene age is an insuperable problem for ${ }^{14} \mathrm{C}$ dating. Can other methods yield reliable dates using lithics and sediments as samples? Obsidian hydration dating has produced dates that are sometimes credible, often clearly erratic (e.g. Bell 1977; Clark 1984; Basgall 1995). A better understanding has been achieved of the 
variables that can affect hydration (Ridings 1996; Jones et al. 1997). It now appears that surface finds are not suitable samples, which unfortunately excludes most Paleoindian-age finds, such as Alaskan fluted points. ${ }^{14} \mathrm{C}$ and cation dating of rock varnish on tools and petroglyphs, once touted as proof of pre-Clovis occupation of western North America (Whitley and Dorn 1993) has been shown to be completely unreliable (Dorn 1996). In the near future, refinement of methods for thermoluminescence (TL) dating of burnt chert and optically stimulated luminescence (OSL) dating of aeolian sand grains (Feathers 1997) may yield reliable and moderately precise dates for these materials (see now, e.g. Rich and Stokes 2001; Hilgers et al. 2001). However, in cases where results can be compared to ${ }^{14} \mathrm{C}$ dates, accuracy has been highly variable, and precision is unimpressive. For example, Roosevelt et al. (1996) obtained 49 AMS and 7 conventional dates for Pedra Pintada, all clustering around 10,500-10,000 BP (ca. 12,500-11,300 cal BP). TL dates ranged from $9530 \pm 780$ to $16,190 \pm 930$; OSL dates were $12,491 \pm 1409,12,536 \pm 4125$, and 13,106 \pm 1628 bp. TL dating of Jinmium Rockshelter in Australia produced grossly erroneous dates in excess of 100,000 years for material that OSL puts at less than 10,000 years old (Roberts et al. 1998). At Cactus Hill, OSL dates for an Early Archaic level (with Fort Nottoway points) are $9189 \pm 1101$ and 12,391 \pm 1864 bp; the expected calibrated age was about 10,000 cal BP (McAvoy et al., undated). It seems that when enough OSL dates are run, the average may correspond pretty closely to the age established by ${ }^{14} \mathrm{C}$.

In the not so distant future, I am confident that we will know, perhaps with decadal precision, exactly when Paleoindians arrived in America, how long it took them to people the continent, and how they affected the native fauna. Establishment of a precise chronology is critical for modeling and understanding the colonization process. Once this has been achieved, there will be profound theoretical repercussions in ethnology, genetics, historical linguistics, demography, and ecology.

\section{REFERENCES}

Ackerman RE. 1992. Earliest stone industries on the North Pacific coast of North America. Arctic Anthropology 29(2):18-27.

Acosta $\mathrm{J}$ de. 1604. The natural and moral history of the Indies. English translation by Grimston E, 1604. Markham CR, editor, 1880.

Adovasio JM. 1993. The ones that will not go away: a broad view of pre-Clovis populations in the New World. In: Soffer O, Praslov ND, editors. From Kostenki to Clovis. New York: Plenum Press. p 199-218.

Adovasio JM, Donahue J, Stuckenrath R. 1990. The Meadowcroft Rockshelter radiocarbon chronology 1975-1990. American Antiquity 55(2):348-54.

Adovasio JM, Pedler D, Donahue J, Stuckenrath R. 1999. No vestige of a beginning nor prospect for an end: two decades of debate on Meadowcroft rockshelter. In: Bonnichsen R, Turnmire KL, editors. Ice Age peoples of North America: environments, origins, and adaptations of the first Americans. Oregon State University Press. p 416-31.

Agenbroad L. 2002. Pygmy mammoths (Mammuthus exilis) and a human presence on Santa Rosa Island: coincidence or extinction? Paper presented at 67th annual meeting of Society for American Archaeology. Denver. 20-24 March.

Agenbroad L, Morris D, Rockwell T, Roth L. 1995. A preliminary report of the recovery of the first nearly complete skeleton of the pygmy (dwarf) mammoth,
Mammuthus exilis, from North America. Paper presented at INQUA Congress XIV, Berlin.

Alberdi MT, Miotti T, Prado JL. 2001. Hippidion saldiasi Roth, 1899 (Equidae, Perissodactyla), at the Piedra Museo site (Santa Cruz, Argentina): its implication for the regional economy and environmental reconstruction. Journal of Archaeological Science 28:411-9.

Anderson DG. 1995. Paleoindian interaction networks in the eastern woodlands. In: Nassaney MS, Sassaman KE, editors. Native American interaction: multiscalar analyses and interpretations in the Eastern woodlands. Knoxville: University of Tennessee Press. p 10-26.

Anderson DG, Faught MK. 1998. The distribution of fluted Paleoindian projectile points: update 1998. Archaeology of Eastern North America 26:163-88.

Anderson DG, Faught MK. 2000. Paleoindian artefact distributions: evidence and implications. Antiquity 74 : 507-13.

Andresen CS, Bjorck S, Bennike O, Heinemeier J, Kromer B. 2000. What do $\delta^{14} \mathrm{C}$ changes across the Gersenzee oscillation/GI-1b event imply for deglacial oscillations? Journal of Quaternary Science 15:203214.

Antevs E. 1935. Age of the Clovis lake clays. Academy of Natural Sciences of Philadelphia Proceedings 87: 304-12.

Antevs E. 1953. Age of the Clovis fluted points with the 
Naco mammoth. American Antiquity 19(1):15-7.

Antevs E. 1959. Geological age of the Lehner mammoth site. American Antiquity 25(1):31-4.

Anthony DW. 1990. Migration in archeology: the baby and the bathwater. American Anthropologist 92(4): 895-914.

Aveleyra A, de Anda L. 1956. The second mammoth and associated artifacts at Santa Isabel Iztapan, Mexico. American Antiquity 22:12-28.

Baales M, Street M. 1996. Hunter-gatherer behavior in a changing late glacial landscape: Allerød archaeology in the central Rhineland, Germany. Journal of Anthropological Research 52:281-316.

Basgall ME. 1995. Obsidian hydration dating of early Holocene assemblages in the Mojave Desert. Current Research in the Pleistocene 12:57-60.

Beaton JM. 1991. Colonizing continents: some problems from Australia and the Americas. In: Dillehay TD, Meltzer DJ, editors. The first Americans: search and research. Boca Raton: CRC Press. p 209-30.

Beck JW, Richards DA, Edwards RL, Silverman BW, Smart PL, Donahue DJ, Herrera-Osterheld S, Burr GS, Calsoyas L, Jull AJT, Biddulph D. 2001. Extremely large variations of atmospheric ${ }^{14} \mathrm{C}$ concentration during the last glacial period. Science 292:2453-8.

Bell RE. 1977. Obsidian hydration studies in highland Ecuador (El Inga). American Antiquity 42(1):68-77.

Bianchi NO, Bailliet G, Bravi CM, Carnese RF, Rothhammer F, Martinez-Marignac VL, Pena SD. 1997. Origin of Amerindian Y-chromosomes as inferred by the analysis of six polymorphic markers. American Journal of Physical Anthropology 102(1):79-89.

Bianchi NO, Catanesi CI, Bailliet G, Martinez-Marignac VL, Bravi CM, Vidal-Rioja LB, Herrera RJ, LopezCamelo JS. 1998. Characterization of ancestral and derived Y-chromosome haplotypes of New World native populations. American Journal of Human Genetics 63(6): 1862-71

Bird J. 1938. Before Magellan. Natural History 41(1): 16-28.

Boldurian A. 1985. Variability in flintworking technology at the Krajacic Site: possible relationships to the Pre-Clovis Paleoindian occupation of the Cross Creek drainage in southwestern Pennsylvania. Unpublished $\mathrm{PhD}$ dissertation. University of Pittsburgh.

Bonnichsen R, Will RT. 1999. Radiocarbon chronology of Northeastern Paleo-American sites: discriminating natural and human burn features. In: Bonnichsen R, Turnmire KL, editors. Ice Age people of North America, environments, origins, and adaptations. Corvallis: Oregon State University Press. p 395-415.

Bradley BA. 1997. Bifacial thinning in the early Upper Paleolithic of Eastern Europe. Chips 9(2):8-9.

Bradley BA, Anikovich M, Giria E. 1995. Early Upper Palaeolithic in the Russian Plain: Streletskayan flaked stone artefacts and technology. Antiquity 69:989-98.

Broecker WS, Andree M, Wolfli W, Oeschger H, Bonani
G, Kennett J, Peteet D. 1988. The chronology of the last deglaciation: implications to the cause of the Younger Dryas event. Paleoceanography 3:1-19.

Broster JB, Norton MR. 1996. Recent Paleoindian research in Tennessee. In: Anderson DG, Sassaman KE, editors. The Paleoindian and Early Archaic Southeast. Tuscaloosa: University of Alabama Press. p 288-97.

Brown MD, Hosseini SH, Torroni A, Bandelt HJ, Allen JC, Schurr TG, Scozzari R, Cruciani F, Wallace DC. 1998. mtDNA haplogroup X: an ancient link between Europe/Western Asia and North America? American Journal of Human Genetics 63(6):1852-61.

Brown P. [in press 1999] The earliest East Asians: a view from the Late Pleistocene and Neolithic of China and Japan. In: Omoto K, editor. Interdisciplinary perspectives on the origins of the Japanese. Kyoto: International Research Center for Japanese Studies.

Bryan AL. 1978. An overview of Paleo-American prehistory from a circum-Pacific perspective. In: Bryan AL, editor. Early Man in America from a Circum-Pacific Perspective. Occasional Papers No. 1. Edmonton: University of Alberta, Department of Anthropology. p 306-27.

Bryan AL, Casamiquela RM, Cruxent JM, Gruhn R, Ochsenius C. 1978. An El Jobo mastodon kill at Taima-Taima, Venezuela. Science 200:1275-7.

Burr GS, Beck JW, Taylor FW, Récy J, Edwards RL, Cabioch G, Corrège T, Donahue DJ, O'Malley JM. 1998. A high-resolution radiocarbon calibration between 11.7 and $12.4 \mathrm{ka} \mathrm{BP}$ derived from ${ }^{230} \mathrm{Th}$ ages of corals from Espiritu Santo Island, Vanuatu. Radiocarbon 40(3):1093-105

Carlson RL. 1991. Clovis from the perspective of the icefree corridor. In: Bonnichsen R, Turnmire KL, editors. Clovis: origins and adaptations. Corvallis, Oregon: Center for the Study of the First Americans. p 81-90.

Carlson RL. 1998. Coastal British Columbia in the light of North Pacific maritime adaptations. Arctic Anthropology 35(1):23-35.

Chard C. 1960. Routes to Bering Strait. American Antiquity 28(2):151-8.

Chatters JC. 2000. The recovery and first analysis of an Early Holocene human skeleton from Kennewick, Washington. American Antiquity 65(2):291-316.

Cinq-Mars J, Morlan RE. 1999. Bluefish Caves and Old Crow Basin: a new rapport. In: Bonnichsen R, Turnmire KL, editors. Ice Age people of North America, environments, origins, and adaptations. Corvallis: Oregon State University Press. p 200-12.

Clark DW. 1984. Some practical applications of obsidian hydration dating in the Subarctic. Arctic 37:91-109.

Clark DW. 1991. The northern (Alaska-Yukon) fluted points. In: Bonnichsen R, Turnmire KL, editors. Clovis: origins and adaptations. Corvallis, Oregon: Center for the Study of the First Americans. p 35-48.

Clark DW, Clark AM. 1983. Paleo-Indians and fluted points: Subarctic alternatives. Plains Anthropologist 
28(102):283-92.

Clausen CJ, Cohen AD, Emiliani C, Holman JA, Stipp JJ. 1979. Little Salt Spring, Florida: a unique underwater site. Science 203:609-14.

Cotter JL. 1937. The occurrence of flints and extinct animals in pluvial deposits near Clovis, New Mexico, pt. IV, Report on the excavations at the gravel pit in 1936. Proceedings of the Philadelphia Academy of Natural Sciences 89:1-16.

Cowan EA, Bornhold BD. 1998. Late Pleistocene geomarine record in Saanich Inlet, British Columbia: results from ODP sites 1033 and 1034. Paper presented at the annual meeting of the Geological Society of America, Toronto.

Cunningham DL, Wescott DJ. 2002. Within-group human variation in the Asian Pleistocene: the three Upper Cave crania. Journal of Human Evolution 42:627-38.

Cushing J, Wenner AM, Noble E, Daily M. 1986. A groundwater hypothesis for the origin of "fire areas" on the northern Channel Islands, California. Quaternary Research 26:207-17.

Davis LB. 2001. Folsom complex antecedents in Montana: the MacHaffie and Indian Creek Paleoindian occupational sequences. Paper presented at meeting of Canadian Archaeological Association, Banff, May 10.

DeFrance SD, Keefer DK, Richardson JB, Umire Alvarez A. 2001. Late Paleo-Indian coastal foragers: specialized extractive behavior at Quebrada Tacahuay, Peru. Latin American Antiquity 12(4):413-26.

Dent RJ. 1999. Shawnee Minisink: new dates on the Paleoindian component. Poster presented at the 64th annual meeting of the Society for American Archaeology, Chicago.

Derenko MV, Malarchuk BA, Dambeva IK, Shaikhaev GO, Dorzhu CM, Nimaev DD, Zakharov IA. 2000 Mitochondrial DNA variation in two Siberian aboriginal populations: implications for the genetic history of North Asia. Human Biology 72(6):945-74.

Derenko MV, Grzybowski T, Malarchuk BA, Czarny J, Miscicka-Sliwka D, Zakharov IA. 2001. The presence of mitochondrial haplogroup X in Altaians from South Siberia. American Journal of Human Genetics 69: 237-41.

Derevianko AP. 1989. The Late Pleistocene sites in the Slendia River basin and their significance for correlation with Upper Paleolithic assemblages of the Pacific. Circum-Pacific Prehistory Conference Program and Abstracts. Seattle. p 36.

Dikov NN. 1996. The Ushki sites, Kamchatka Peninsula. In: West FH, editor. American beginnings: the prehistory and palaeoecology of Beringia. University of Chicago Press. p 244-50.

Dikov NN, Titov EE. 1984. Problems of the stratification and periodization of the Ushki sites. Arctic Anthropology 21(2):1-68.

Dillehay TD. 1989. Monte Verde, a Late Pleistocene settlement in Chile. Volume 1. Palaeoenvironment and site context. Washington DC: Smithsonian Institution
Press.

Dillehay TD. 1997. Monte Verde, a Late Pleistocene settlement in Chile. Volume 2. The archaeological context and interpretation. Washington, DC: Smithsonian Institution Press.

Dillehay TD. 2002. Errata. Monte Verde, a Late Pleistocene settlement in Chile. Volume 2. The archaeological context and interpretation. Washington, DC: Smithsonian Institution Press.

Dillehay TD, Meltzer DJ. 1991. Finale: processes and prospects. In: Dillehay TD, Meltzer DJ, editors. The first Americans: search and research. Boca Raton: CRC Press. p 287-94.

Dincauze D. 1984. An archaeo-logical evaluation of the case for pre-Clovis occupations. In: Wendorf F, Close A, editors. Advances in world archaeology. Volume 3. New York: Academic Press. p 275-323.

Dixon EJ. 1999. Bones, boats, and bison: archeology and the first colonization of western North America. Albuquerque: University of New Mexico Press.

Donohue JA. 1998. The chronology of the Jim Pitts site and implications for the temporal placement of the Goshen-Plainview complex in the northwestern Plains. Paper presented at 63rd annual meeting of Society for American Archaeology, Seattle.

Dorn RI. 1996. Uncertainties in the radiocarbon dating of organics associated with rock varnish: a plea for caution. Physical Geography 17(6):585-91.

Elias SA. 2000. Late Pleistocene climates of Beringia based on analysis of fossil beetles. Quaternary $R e$ search 53(2):229-35.

Elston RG, Cheng X, Madsen DB, Kan Z, Bettinger RL, Jingzen L, Brantingham PJ, Huiming W, Jun Y. 1997. New dates for the North China Mesolithic. Antiquity 71(274):985-93.

Erlandson JM. 1994. Early hunter-gatherers of the California coast. New York: Plenum Press.

Erlandson JM. 1998. Paleocoastal occupations of Daisy Cave, San Miguel Island, California. Paper presented at 63rd Annual Meeting of the Society for American Archaeology, Seattle.

Erlandson JM, Kennett DL, Ingram BL, Guthrie DA, Morris DP, Tveskov MA, West GJ, Walker PL. 1996. An archaeological and paleontological chronology for Daisy Cave (CA-SMI-261), San Miguel Island, California. Radiocarbon 38(2):355-73.

Erlandson J, Moss ML. 1996. The Pleistocene-Holocene transition along the Pacific coast of North America. In: Straus LG, Eriksen BV, Erlandson JM, Yesner DR, editors. Humans at the end of the Ice Age: the archaeology of the Pleistocene-Holocene transition. New York: Plenum Press. p 278-302.

Fairbanks RG, Charles CD, Wright JD. 1992. Origin of global meltwater pulses. In: Taylor RE, Long A, Kra $\mathrm{RS}$, editors. Radiocarbon after four decades. New York: Springer-Verlag. p 473-500.

Faught MK. 1996. Clovis origins and underwater prehistoric archaeology in northwestern Florida. $\mathrm{PhD}$ disser- 
tation. University of Arizona, Department of Anthropology.

Feathers JK. 1997. The application of luminescence dating in American archaeology. Journal of Archaeological Method and Theory 4(1):1-66.

Fedje DW, Josenhans H. 2000. Drowned Forests and Archaeology on the Continental Shelf of British Columbia, Canada. Geology 28(2):99-102.

Fedje DW, McSporran JB, Mason AR. 1996. Early Holocene archaeology and paleoecology at the Arrow Creek sites in Gwaii Haanas. Arctic Anthropology 33(1):116-42.

Ferring CR. 1995. The Late Quaternary geology and archaeology of the Aubrey Clovis site, Texas: a preliminary report. In: Johnson E, editor. Ancient peoples and landscapes. Lubbock: Museum of Texas Tech University. p 273-81.

Ferring CR. 2001. The archaeology and paleoecology of the Aubrey Clovis site (41DN479), Denton County, Texas. Report from Center for Environmental Archaeology, University of North Texas, to U.S. Army Corps of Engineers, Fort Worth District.

Fiedel SJ. 1998. Rapid migrations by Arctic hunting peoples: Clovis and Thule. Paper presented at 63rd annual meeting of Society for American Archaeology, Seattle, March 26.

Fiedel SJ. 1999a. Older than we thought: implications of corrected dates for Paleoindians. American Antiquity 64(1):95-116

Fiedel SJ. 1999b. Artifact provenience at Monte Verde: confusion and contradictions. Scientific American Discovering Archaeology 1(6):Special Report 1-12.

Fiedel SJ. 2000. The peopling of the New World: present evidence, new theories, and future directions. Journal of Archaeological Research 8(1):39-103.

Fiedel SJ, Anthony D. 1979. The diffusion of the early European Neolithic: a reconsideration. Paper delivered at the Second Eastern European Archaeology (Hleb i Vino) Conference. University of Pennsylvania, Philadelphia.

Fladmark KR. 1979. Routes: alternate migration corridors for early man in North America. American Antiquity 44:55-69.

Fladmark KR. 1983. Times and places: environmental correlates of mid-to-late Wisconsinan human population expansion in North America. In: Shutler R Jr, editor. Early man in the New World. Beverly Hills: Sage Publications. p 13-42.

Fladmark KR, Driver JC, Alexander D. 1988. The Paleoindian component at Charlie Lake Cave (HbRf 39), British Columbia. American Antiquity 53(2):371-84.

Flannery TF. 1999. Debating extinction. Science 283: 182-3.

Flegenheimer N. 1986-1987. Excavaciones en el sitio 3 de la localidad Cerro La China (Prov. de Bs. As.) Relaciones de la Sociedad Argentina de Antropología $\mathrm{T}$. XVII-I:7-28.

Flegenheimer N, Zarate M. 1997. Considerations on ra- diocarbon and calibrated dates from Cerro La China and Cerro El Sombrero, Argentina. Current Research in the Pleistocene 14:27-8.

Foit FF Jr, Mehringer PJ Jr, Sheppard JC. 1993. Age, distribution, and stratigraphy of Glacier Peak tephra in eastern Washington and western Montana, United States. Canadian Journal of Earth Sciences 30:53552.

Friedrich M, Kromer B, Spurk M, Hofmann J, Kaiser KF. 1999. Paleo-environment and radiocarbon calibration as derived from Lateglacial/Early Holocene tree-ring chronologies. Quaternary International 61:27-39.

Friedrich M, Kromer B, Kaiser KF, Spurk M, Hughen KA, Johnsen SJ. 2001. High-resolution climate signals in the Bølling-Allerød Interstadial (Greenland Interstadial 1) as reflected in European tree-ring chronologies compared to marine varves and ice-core records. Quaternary Science Reviews 20:1223-32.

Frison GC. 1991. The Goshen Paleoindian complex: New data for Paleoindian research. In: Bonnichsen R, Turnmire KL, editors. Clovis: origins and adaptations. Corvallis, Oregon: Center for the Study of the First Americans. p 133-52.

Frison GC. 1993. The North American Paleoindian: a wealth of new data but still much to learn. Plains Anthropologist 38(145), Memoir 27. p 5-16.

Frison GC. 1996. The Mill Iron site. Albuquerque: University of New Mexico Press.

Goddard I, Campbell L. 1994. The history and classification of American Indian languages: what are the implications for the peopling of the Americas? In: Bonnichsen R, Steele DG, editors. Method and theory for investigating the peopling of the Americas. Corvallis, Oregon: Center for the Study of the First Americans. p 189-208.

Goebel T. 1993. Characterizing the Siberian Middle-Upper Paleolithic transition. Paper presented at 58th Annual Meeting of the Society for American Archaeology, St Louis, Missouri, USA.

Goebel T. 1998. The Siberian Upper Paleolithic: hard environments, limiting factors, and human range expansion into northern Asia. Paper presented at 63rd Annual Meeting of the Society for American Archaeology, Seattle, 25-29 March.

Goebel T, Aksenov M. 1995. Accelerator radiocarbon dating of the initial Upper Palaeolithic in southeastern Siberia. Antiquity 69:349-57.

Goebel T, Powers R, Bigelow N. 1991. The Nenana complex of Alaska and Clovis origins. In: Bonnichsen R, Turnmire KL, editors. Clovis: origins and adaptations. Corvallis, Oregon: Center for the Study of the First Americans. p 49-80.

Goebel T, Waters MR, Buvit I, Konstantinov MV, Konstantinov AV. 2000. Studenoe-2 and the origins of microblade technologies in the Transbaikal, Siberia. Antiquity 74:567-75.

Goebel T, Waters MR, Dikova M. 2002. The Ushki sites, Kamchatka, and the Pleistocene peopling of the 
Americas. Paper presented at 67th annual meeting of Society for American Archaeology, Denver. 20-24 March.

Goodyear AC. 1997. Clovis utilization at southeastern U.S. quarries: the Big Pine Tree site, Allendale, South Carolina. Paper presented at 62nd Annual Meeting of the Society for American Archaeology, Nashville.

Goslar T, Wohlfarth B, Bjorck S, Possnert G, Bjorck J. 1999. Variations of atmospheric ${ }^{14} \mathrm{C}$ concentrations over the Allerød-Younger Dryas transition. Climate Dynamics 15:29-42.

Graham R. 1998. Mammals' eye view of environmental change in the United States at the end of the Pleistocene. Paper presented at 63rd Annual Meeting of the Society for American Archaeology, Seattle.

Graham R, Stafford T, Lundelius E, Semken H, Southon J. 2002. C-14 Chronostratigraphy and Litho-stratigraphy of Late Pleistocene Megafauna Extinctions in the New World. Paper presented at 67th annual meeting of Society for American Archaeology, Denver, 20-24 March.

Grayson DK. 1991. Late Pleistocene mammalian extinction in North America: taxonomy, chronology, and explanations. Journal of World Prehistory 5(3):193-231.

Greenberg JH. 1987. Language in the Americas. Palo Alto, California: Stanford University Press.

Greenman E. 1963. The Upper Palaeolithic and the New World. Current Anthropology 4:41-91.

Gruhn R. 1988. Linguistic evidence in support of the coastal route of earliest entry into the New World. Man 23:77-100.

Gruhn R. 1994. The Pacific Coast route of initial entry: an overview. In: Bonnichsen R, Steele DG, editors. Method and theory for investigating the peopling of the Americas. Corvallis, Oregon: Center for the Study of the First Americans. p 249-56.

Guilday JE, Parmalee PW. 1982. Vertebrate faunal remains from Meadowcroft Rockshelter, Washington County, Pennsylvania. In: Carlisle RC, Adovasio JM, editors. Meadowcroft: collected papers on the archaeology of Meadowcroft Rockshelter and the Cross Creek drainage. p 163-74.

Hajdas I, Ivy-Ochs SD, Bonani G, Lotter AF, Zollitschka B, Schluchter C. 1995. Radiocarbon age of the Laacher See tephra: 11,230 \pm 40 BP. Radiocarbon 37(2): 149-54.

Hamilton TD, Goebel T. 1999. Late Pleistocene peopling of Alaska. In: Bonnichsen R, Turnmire KL, editors. Ice Age people of North America, environments, origins, and adaptations. Covallis: Oregon State University Press. p 156-99.

Hanebuth T, Stattegger K, Grootes PM. 2000. Rapid flooding of the Sunda Shelf: a Late-Glacial sea-level record. Science 288:1033-5.

Haury EW, Sayles EB, Wasley WW. 1959. The Lehner Mammoth site, southeastern Arizona. American Antiquity 25(1):2-30.
Haynes CV Jr. 1964. Fluted projectile points: their age and dispersion. Science 145:1408-13.

Haynes CV Jr. 1966. Elephant-hunting in North America. Scientific American 214(6):104-12.

Haynes CV Jr. 1974. Paleoenvironments and cultural diversity in late Pleistocene South America: a reply to A. L. Bryan. Quaternary Research 4:378-82.

Haynes CV Jr. 1980b. Paleoindian charcoal from Meadowcroft Rock Shelter: is contamination a problem? American Antiquity 45:583-7.

Haynes CV Jr. 1982. Were Clovis progenitors in Beringia? In: Hopkins DM, Matthews JV, Schweger CE, Young SB, editors. Paleoecology of Beringia. New York: Academic Press. p 383-98.

Haynes CV Jr. 1987. Clovis origin update. The Kiva 52(2):83-93.

Haynes CV Jr. 1991a. More on Meadowcroft radiocarbon chronology. The Review of Archaeology 12(1):814.

Haynes CV Jr. 1991b. Geoarchaeological and paleohydrological evidence for a Clovis-age drought in North America and its bearing on extinction. Quaternary Research 35:438-50.

Haynes CV Jr. 1992. Contributions of radiocarbon dating to the geochronology of the peopling of the New World. In: Taylor RE, Long A, Kra RS, editors. Radiocarbon after four decades. New York: Springer-Verlag. p 355-74.

Haynes CV Jr. 1993. Clovis-Folsom geochronology and climatic change. In: Soffer O, Praslov ND, editors. From Kostenki to Clovis: Upper Paleolithic-Paleoindian adaptations. New York: Plenum Press. p 219-36.

Haynes CV Jr. 1998. Geochronology of the stratigraphic manifestation of paleoclimatic events at Paleoindian sites. Paper presented at 63rd Annual Meeting of the Society for American Archaeology, Seattle.

Haynes CV Jr [no date]. Clovis, pre-Clovis, climate change, and extinction. Unpublished manuscript.

Haynes CV Jr, Donahue DJ, Jull AJT, Zabel TH. 1984. Application of accelerator dating to fluted point Paleoindian sites. Archaeology of Eastern North America 12:184-91.

Haynes, G. 1999. The role of mammoths in rapid Clovis dispersal. In: Haynes G, Klimowicz J, Reumer WF, editors. Mammoths and the Mammoth fauna: studies of an extinct ecosystem. DEINSEA 6:9-38.

Heaton TH, Talbot SL, Shields GF. 1996. An Ice Age refugium for large mammals in the Alexander Archipelago, Southeast Alaska. Quaternary Research 46:18692.

Hilgers A, Murray AS, Schlaak N, Radtke U. 2001. Comparison of quartz OSL protocols using Lateglacial and Holocene dune sands from Brandenburg, Germany. Quaternary Science Reviews 20(5-9):731-6.

Hoffecker JF, Powers WR, Goebel T. 1993. The colonization of Beringia and the peopling of the New World. Science 259:46-53. 
Holdaway R, Jacomb C. 2000. Rapid extinction of the Moas (Aves:Dinornithiformes): model, test, and implications. Science 287:2250-4.

Holmes CE. 1998. New data pertaining to Swan Point, the oldest microblade site known in Alaska. Current Research in the Pleistocene 15:21-2.

Howells W. 1967. Mankind in the making. Garden City: Doubleday.

Hughen KA, Overpeck JT, Lehman SJ, Kashgarian M, Southon JR, Peterson LC, Alley R, Sigman DM. 1998. Deglacial changes in ocean circulation from an extended radiocarbon calibration. Nature 391:65-8.

Hughen KA, Southon JR, Lehman SJ, Overpeck JT. 2000. Synchronous radiocarbon and climate shifts during the last deglaciation. Science 290:1951-4.

Ingman M, Kaessmann H, Paabo S, Gyllensten U. 2000. Mitochondrial genome variation and the origin of modern humans. Nature 408:708-13.

Irwin-Williams C. 1967. Association of early man with horse, camel and mastodon at Hueyatlaco, Valsequillo (Puebla, Mexico). In: Martin PS, editor. Pleistocene extinctions. New Haven: Yale University Press. p 33747.

Irwin-Williams C. 1978. Summary of archaeological evidence from the Valsequillo region, Puebla, Mexico. In: Browman DL, editor. Cultural continuity in $\mathrm{Me}$ soamerica. London: Mouton. p 7-22.

Irwin-Williams C. 1981. Letter: commentary on geologic evidence for age of deposits at Hueyatlaco archaeological site, Valsequillo, Mexico. Quaternary Research 16:258

Ives JW, Beaudoin AW, Magne MPR. 1993. Evaluating the role of a Western Corridor in the peopling of the Americas. Paper presented at Circum-Pacific Prehistory Conference, 2-6 August 1989. Revised for Proceedings volume, in press.

Jackson LE Jr, Duk-Rodkin A. 1996. Quaternary geology of the ice-free corridor: Glacial controls on the peopling of the New World. In: Akazawa T, Szathmary EJE, editor. Prehistoric Mongoloid dispersals. Oxford: Oxford University Press. p 214-27.

Johnson DL. 1983. The California continental borderland: landbridges, watergaps and biotic dispersals. In: Masters PM, Fleming NC, editors. Quaternary coastlines and marine archaeology: towards the prehistory of land bridges and continental shelves. London: Academic Press. p 481-528.

Johnson MF. 1997. Confirmation of McAvoy's early Cactus Hill sequence. Paper presented at Middle Atlantic Archaeological Conference, Ocean City, Maryland.

Jones MD, Sheppard PJ, Sutton DG. 1997. Soil temperature and obsidian hydration dating: a clarification of variables affecting accuracy. Journal of Archaeological Science 24:505-17.

Josenhans H, Fedje D, Pienitz R, Southon J. 1997. Early Humans and Rapidly Changing Holocene Sea Levels in the Queen Charlotte Islands-Hecate Strait, British Columbia, Canada. Science 277:71-4.

Kaiser KF. 1989. Late glacial reforestation in the Swiss Mittelland, as illustrated by the Dättnau Valley. In: Rose J, Schluchter C, editors. Quaternary type sections: imagination or reality. Rotterdam: Balkema. $\mathrm{p}$ 161-78.

Kaiser KF. [no date]. ${ }^{14} \mathrm{C}$ and dendro years, Dättnau: Boelling/Alleroed chronologies. Graph formerly posted at www.wsl.ch/forest/dendro/images/dendroy.jpg.

Kamminga J, Wright RVS. 1988. The Upper Cave at Zhoukoudian and the origins of the Mongoloids. Journal of Human Evolution 17:739-67.

Karafet TM, Zegura SL, Posukh O, Osipova L, Bergen A, Long J, Goldman D, Klitz W, Harihara S, de Knijff P, Griffiths RC, Templeton AR, Hammer MF. 1999. Ancestral Asian source(s) of New World Y-chromosome founder haplotypes. American Journal of Human Genetics 64(3):817-31.

Keefer DK, deFrance SD, Moseley ME, Richardson JB III, Satterlee DR, Day-Lewis A. 1998. Early maritime economy and El Niño events at Quebrada Tacahuay, Peru. Science 281(5384):1833-5.

Kelly RL. 1987. A comment on the Pre-Clovis deposits at Meadowcroft Rockshelter. Quaternary Research 27:332-4.

Kelly RL, Todd LC. 1988. Coming into the country: Early Paleoindian hunting and mobility. American Antiquity 53(2):231-44.

King MB, Slobodin SB. 1996. A fluted point from the Uptar site, northeastern Siberia. Science 273: 634-6.

Kipnis R. 1998. Early hunter-gatherers in the Americas: Perspectives from central Brazil. Antiquity 72:581-92.

Kiryak MA. 1996. Bolshoi Elgakhchan 1 and 2, Omolon River basin, Magadan district. In: West FH, editor. American beginnings: the prehistory and palaeoecology of Beringia. Chicago: University of Chicago Press. p 228-36.

Kitigawa H, van der Plicht J. 1998. Atmospheric radiocarbon calibration to $45,000 \mathrm{yr}$ B.P.: Late Glacial fluctuations and cosmogenic isotope production. Science 279:1187-90.

Kitigawa H, van der Plicht J. 2000. Atmospheric radiocarbon calibration beyond 11,900 cal BP from Lake Suigetsu laminated sediments. Radiocarbon 42(3): 369-80.

Kolman CJ, Sambuughin N, Bermingham E. 1996. Mitochondrial DNA analysis of Mongolian populations and implications for the origin of New World founders. Genetics 142(4):1321-34.

Kovanen DJ, Easterbrook DJ. 2002. Paleodeviations of radiocarbon marine reservoir values for the northeast Pacific. Geology 30(3):243-6.

Kunz ML, Reanier RE. 1994. Paleoindians in Beringia: evidence from Arctic Alaska. Science 263: 660-2.

Kuzmin YV, Orlova LA. 2000. The Neolithization of Si- 
beria and the Russian Far East: radiocarbon evidence. Antiquity 74:356-64.

Kuzmin YV, Orlova LA. 1998. Radiocarbon chronology of the Siberian Paleolithic. Journal of World Prehistory 12(1):1-53.

Kuzmin YV, Tankersley KB. 1996. The colonization of eastern Siberia: an evaluation of the Paleolithic age radiocarbon dates. Journal of Archaeological Science 23:577-85.

Lahr MM. 1995. Patterns of modern human diversification: implications for Amerindian origins. Yearbook of Physical Anthropology 38:163-98.

Lea PD. 1996. Vertebrate tracks in Pleistocene eolian sand-sheet deposits of Alaska. Quaternary Research 45(2):226-40.

Lell JT, Sukernik RI, Starikovskaya YB, Su B, Jin L, Schurr TG, Underhill PA, Wallace DC. 2002. The dual origin and Siberian affinities of Native American Y chromosomes. American Journal of Human Genetics 70:192-206.

Long A, Martin PS. 1974. Death of American ground sloths. Science 186:638-40.

Long A, Martin PS, Lagiglia HA. 1998. Ground sloth extinction and human occupation at Gruta del Indio, Argentina. Radiocarbon 40(2):693-700.

Loy TH, Dixon EJ. 1998. Blood residues on fluted points from eastern Beringia. American Antiquity 63(1):2146.

Lynch TF. 1983. The Paleo-Indians. In: Jennings JD, editor. Ancient South Americans. San Francisco: Freeman. p 86-137.

Lynch TF. 1990. Glacial-age man in South America? A critical review. American Antiquity 55(1): 12-36.

MacDonald DH. 1998. Subsistence, sex and cultural transmission in Folsom culture. Journal of Anthropological Archaeology 17:217-39.

MacDonald GF. 1968. Debert, a Paleo-Indian site in central Nova Scotia. Anthropology Papers No. 16, National Museums of Canada, Ottawa.

MacNeish RS. 1983. Mesoamerica. In: Shutler R Jr, editor. Early Man in the New World. Beverly Hills: Sage Publications. p 125-36.

Malhi RS, Eshleman JA, Greenberg JA, Weiss DA, Schultz Shook BA, Kaestle FA, Lorenz JG, Kemp BM, Johnson JR, Smith DG. 2002. The structure of diversity within New World mitochondrial DNA haplogroups: implications for prehistory of North America. American Journal of Human Genetics 70:905-19.

Mandryk CAS. 1998. Evaluating paleoenvironmental constraints on interior and coastal entry routes into North America. Paper presented at 63rd annual meeting of Society for American Archaeology, Seattle.

Martin PS. 1973. The discovery of America. Science 179: 969-74.

Mayer-Oakes WJ. 1984. Fluted projectile points-A North American shibboleth viewed in South American perspective. Archaeology of Eastern North Amer- ica 12:231-47.

McAvoy JM, McAvoy LD. 1997. Archaeological investigations of site 44SX202, Cactus Hill, Sussex County, Virginia. Virginia Department of Historic Resources, Research Report Series No. 8, Richmond.

McAvoy JM, Baker JC, Feathers JK, Hodges RL, McWeeney LJ, Whyte TR. [no date]. Summary of Research at the Cactus Hill Archaeological site, 44SX202, Sussex County, Virginia: Report to the National Geographic Society in compliance with stipulations of grant \#6345-98.

McGhee R. 1984. Thule prehistory of Canada. In: Damas D, editor. Arctic, handbook of North American Indians. Volume 5. Washington DC: Smithsonian Institution Press. p 369-76.

McNett CW, editor. 1985. Shawnee Minisink: a stratified Paleoindian-Archaic site in the upper Delaware Valley of Pennsylvania. New York: Academic Press.

Mead JI. 1980. Is it really that old? A comment about the Meadowcroft Rockshelter "overview." American Antiquity 45(3):579-81.

Mehringer PJ Jr. Foit FF Jr. 1990. Volcanic ash dating of the Clovis cache at East Wenatchee, Washington. $\mathrm{Na}$ tional Geographic Research 6(4):495-503.

Mehringer PJ Jr, Sheppard JC, Foit FF Jr. 1984. The age of Glacier Peak tephra in west-central Montana. Quaternary Research 21:36-41.

Meighan CW. 1983. Early man in the New World. In: Masters PM, Fleming NC, editors. Quaternary coastlines and marine archaeology: towards the prehistory of land bridges and continental shelves. London: Academic Press. p 441-62.

Meltzer DJ. 1997. Monte Verde and the Pleistocene peopling of the Americas. Science 276:754-5.

Meltzer DJ, Adovasio JM, Dillehay TD. 1994. On a Pleistocene human occupation at Pedra Furada, Brazil. Antiquity 68:261.

Meltzer DJ, Grayson DK, Ardila G, Barker AW, Dincauze DF, Haynes CV, Mena F, Nunez L, Stanford DJ. 1997. On the Pleistocene Antiquity of Monte Verde, Southern Chile. American Antiquity 62(4):659-63.

Meltzer DJ, Mead JI. 1985. Dating Late Pleistocene extinctions: Theoretical issues, analytical bias, and substantive results. In: Mead JI, Meltzer DJ, editors. Environments and extinctions: man in Late Glacial North America. Orono: Center for the Study of Early Man. p $145-74$.

Merriwether DA, Rothhammer F, Ferrell RE. 1994. Genetic variation in the New World: ancient teeth, bone, and tissue as sources of DNA. Experientia 50:592601.

Miller GH, Magee JW, Johnson BJ, Fogel ML, Spooner NA, McCulloch MT, Ayliffe LK. 1999. Pleistocene extinction of Genyornis newtoni: human impact on Australian megafauna. Science 283:205-8.

Mochanov YA, Fedoseeva SA. 1996a. Berelekh, Allakhovsk region. In: West FH, editor. American begin- 
nings: the prehistory and palaeoecology of Beringia. Chicago: University of Press. p 218-21.

Mochanov YA, Fedoseeva SA. 1996b. Dyuktai Cave. In: West FH, editor. American beginnings: the prehistory and palaeoecology of Beringia. Chicago: University of Press. p 164-71.

Morlan RE. 1991. Peopling of the New World: a discussion. In: Bonnichsen R, Turnmire KL, editors. Clovis: origins and adaptations. Corvallis, Oregon: Center for the Study of the First Americans. p 303-8.

Morlan RE, Cinq-Mars J. 1982. Ancient Beringians: human occupation in the Late Pleistocene of Alaska and the Yukon Territory. In: Hopkins DM, Matthews JV Jr, Schweger CE, Young SB, editors. Paleoecology of Beringia. New York: Academic Press. p 353-81.

Morrow J, Morrow T. 1999. Geographic variation in fluted projectile points: a hemispheric perspective. American Antiquity 64(2):215-30.

Nami HG. 1994. Reseña sobre los avances de la arqueología finipleistocénica del extremo sur de Sudamérica. Revista Chungara 26(2):145-63.

Nami HG. 1996. New assessments of early human occupations in the Southern Cone. In: Akazawa T, Szathmáry EJE, editors. Prehistoric Mongoloid dispersals. Oxford: Oxford University Press. p 256-69.

Neumann GK. 1952. Archeology and race in the American Indian. In: Griffin JB, editor. Archeology of Eastern United States. Chicago: University of Chicago Press. p 13-34.

Neves WA, Powell JF, Prous A, Ozolin EG. 1998. Lapa Vermelha IV, Hominid 1: morphological affinities of the earliest known American. American Journal of Physical Anthropology Supplement 26:169.

Núñez L, Santoro C. 1990. Primeros poblamientos en el cono sur de America (XII-IX milenio A.P.) Revista de Arqueologia Americana 1:91-139.

Orr PC. 1968. Prehistory of Santa Rosa Island. Santa Barbara, California: Santa Barbara Museum of Natural History.

Overstreet DF, Stafford TW Jr. 1997. Additions to a revised chronology for cultural and non-cultural mammoth and mastodon fossils in the southwestern Lake Michigan basin. Current Research in the Pleistocene 14:70-1.

Pearson GA. 1997b. Non-Mongoloid Pleistocene expansions: old and new ideas on the origins of the first Americans. Paper presented at 24th annual meeting of Alaska Anthropological Association, White Horse, Yukon.

Pearson GA. 1998. Pan-American Paleoindian dispersals as seen through the lithic reduction strategies and tool manufacturing techniques at the Guardiria site, Turrialba valley, Costa Rica. Paper presented at 63rd annual meeting of Society for American Archaeology, Seattle.

Pichardo M. 2000. Redating Iztapan and Valsequillo, Mexico. Radiocarbon 42(2):305-10.
Politis G. 1997. The peopling of the Americas viewed from the Southern Cone. Paper presented at 62nd Annual Meeting of the Society for American Archaeology, Nashville.

Prous A, Fogaça E. 1999. Archaeology of the Pleistocene-Holocene boundary in Brazil. Quaternary International 53/54:21-41.

Quade J, Forester RM, Pratt WL, Carter C. 1998. Black mats, spring-fed streams, and Late Glacial age recharge in the southern Great Basin. Quaternary Research 49:129-48.

Ranere AJ. 1997. Paleoindian expansion into tropical America: the view from Central America. Paper presented at 62nd Annual Meeting of the Society for American Archaeology, Nashville.

Ranere AJ, Cooke RG. 1991. Paleoindian occupation in the Central American tropics. In: Bonnichsen R, Turnmire KL, editors. Clovis: origins and adaptations. Corvallis, Oregon: Center for the Study of the First Americans. p 237-54.

Ray JH, Lopinot NH, Hajic ER, Mandel RD. 1998. The Big Eddy site: a multicomponent Paleoindian site on the Ozark border, southwest Missouri. Plains Anthropologist 43(163):73-81.

Reanier RE. 1995. The antiquity of Paleoindian materials in northern Alaska. Arctic Anthropology 32(1):31-50.

Rensberger B. 1997. Putting a new face on prehistory: skeletons suggest Caucasoid early Americans. Washington Post. April 15.

Rich J, Stokes S. 2001. Optical dating of geoarchaeologically significant sites from the southern High Plains and south Texas, USA. Quaternary Science Reviews 20(5-9):949-59.

Ridings R. 1996. Where in the world does obsidian hydration dating work? American Antiquity 61(1):13648

Roberts R, Bird M, Olley J, Galbraith R, Lawson E, Laslett G, Yoshida H, Jones R, Fullagar R, Jacobsen G, Hua Q. 1998. Optical and radiocarbon dating at Jinmium rockshelter in northern Australia. Nature 393: 358-60.

Roberts RG, Flannery TF, Ayliffe LK, Yoshida H, Olley JM, Prideaux GJ, Laslett GM, Baynes A, Smith MA, Jones R, Smith BL. 2001. New ages for the last Australian megafauna: continent-wide extinction about 46,000 years ago. Science 292(5523): 1888.

Roosevelt AC, Lima da Costa M, Lopes Machado C, Michab M, Mercier N, Vallada H, Feathers J, Barnet W, Imazio da Silveira M, Henderson A, Sliva J, Chernoff B, Reese DS, Holman JA, Toth N, Schick K. 1996. Paleoindian cave dwellers in the Amazon: the peopling of the Americas. Science 272:373-84.

Sandweiss DH, McInnis H, Burger RL, Cano A, Ojeda B, Paredes R, del Carmen Sandweiss M, Glascock MR. 1998. Quebrada Jaguay: early South American maritime adaptations. Science 281 (5384):1830-2.

Sandweiss DH, Tanner B, Sanger D, Andrus F, Piperno 
D. 2000. Paleoindian-age domestic structure at a Peruvian fishing site. Paper presented at 65th annual meeting of Society for American Archaeology, Philadelphia.

Santos FR, Pandya A, Tyler-Smith C, Pena SDJ, Schanfield M, Leonard WR, Osipova Crawford MH, Mitchell RJ. 1999. The Central Siberian origin for Native American Y chromosomes. American Journal of $\mathrm{Hu}$ man Genetics 64:619-28.

Schurr TG. 2000. Mitochondrial DNA and the peopling of the New World. American Scientist 88:246-53.

Schwander J, Eicher U, Ammann B. 2000. Oxygen isotopes of lake marl at Gerzensee and Leysin (Switzerland) covering the Younger Dryas and two minor oscillations and their correlation to the GRIP ice core. Palaeogeography, Palaeoclimatology, Palaeoecology 159:203-14.

Sellars VS. 1999. The accuracy of AMS ${ }^{14} \mathrm{C}$ dates on human bone and associated vertebrate remains-determining chronologies for late Pleistocene human occupation of the New World. Poster presented at "Clovis and Beyond" conference, Santa Fe, New Mexico.

Sellards EH. 1952. Early man in America. Austin: University of Texas Press.

Semaw S. 2000. The world's oldest stone artifacts from Gona, Ethiopia: their implications for understanding stone technology and patterns of human evolution between 2.6-1.5 million years ago. Journal of Archaeological Science 27(12):1197-214.

Semino O, Passarino G, Oefner PJ, Lin AA, Arbuzova S, Beckman LE, De Benedictis G, Francalacci P, Kouvatsi A, Limborska S, Marcikae M, Mika A, Mika B, Primorac D, Santachiara-Benerecetti AS, CavalliSforza LL, Underhill PA. 2000. The genetic legacy of Paleolithic Homo sapiens in extant Europeans: A Y chromosome perspective. Science 290:1155-9.

Snarskis M J. 1979. Turrialba: a Paleoindian quarry and workshop site in eastern Costa Rica. American Antiquity 44(1):110-24.

Southon J. 2002 A first step to reconciling the GRIP and GISP2 ice-core chronologies, 0-14,500 yr B.P. Quaternary Research 57:32-7.

Sowers T, Bender M. 1995. Climate records covering the last deglaciation. Science 269: 210-4.

Stafford TW Jr. 1994. Accelerator C-14 dating of human fossil skeletons: assessing accuracy and results on New World specimens. In: Bonnichsen R, Steele DG, editors. Method and theory for investigating the peopling of the Americas. Corvallis, Oregon: Center for the Study of the First Americans. p 45-56.

Stafford TW Jr. Sellars VS, Johnson JR. 2002. Chronostratigraphy at Arlington Springs, a Paleoindian site in insular California. Paper presented at 67 th annual meeting of Society for American Archaeology, Denver, 20-24 March.

Stanford D. 1983. Pre-Clovis occupation south of the ice sheets. In: Shutler R Jr. Early man in the New World.
Beverly Hills: Sage Publications. p 65-72.

Stanford D. 1998. The first Americans: a new perspective. Paper presented at 33rd Annual Symposium of Archeological Society of Maryland, Crownsville, 18 April.

Steele DG, Powell JF. 1992. Peopling of the Americas: paleobiological evidence. Human Biology 64:303-36.

Steele DG, Powell JF. 1994. Paleobiological evidence of the peopling of the Americas: a morphometric view. In: Bonnichsen R, Steele DG, editors. Method and theory for investigating the peopling of the Americas. Corvallis, Oregon: Center for the Study of the First Americans. p 141-64.

Steele J, Politis G, Pettitt P. 2001. AMS radiocarbon dating of the earliest Paleoindian occupation of the southern cone of South America. Paper presented at 66th Annual Meeting of the Society for American Archaeology, New Orleans, 18-22 April.

Steen-McIntyre V, Fryxell R, Malde HE. 1981. Geologic evidence for age of deposits at Hueyatlaco archeological site, Valsequillo, Mexico. Quaternary Research 16:1-17.

Straus LG. 2000. Solutrean settlement of North America? A review of reality. American Antiquity 65(2): 219-26.

Stuiver M, Reimer PJ, Bard E, Beck JW, Burr GS, Hughen KA, Kromer B, McCormac FG, van der Plicht J, Spurk M. 1998. INTCAL98 radiocarbon age calibration 24,000-0 cal BP. Radiocarbon 40(3):104183.

Surovell TA. 2000. Early Paleoindian women, children, mobility, and fertility. American Antiquity 65:493508.

Szabo BJ, Malde HE, Irwin-Williams C. 1969. Dilemma posed by uranium-series dates on archaeologically significant bones from Valsequillo, Puebla, Mexico. Earth and Planetary Science Letters 6: 237-44.

Tankersley KB, Munson CA. 1992. Comments on the Meadowcroft Rockshelter Radiocarbon Chronology and the Recognition of Coal Contaminants. American Antiquity 57:321-6.

Tankersley KB, Tompkins C, Kuzmin YV. 1996. Clovis precursors: the Siberian roots of fluted points. Paper presented at 61st Annual Meeting of the Society for American Archaeology, New Orleans, 10-14 April.

Taylor RE. 1991. Frameworks for dating the Late Pleistocene peopling of the Americas. In: Dillehay TD, Meltzer DJ, editor. The first Americans: search and research. Boca Raton: CRC Press. p 77-112.

Taylor RE, Payen LA, Prior CA, Slota PJ Jr, Gillespie R, Gowlett JAJ, Hedges REM, Jull AJT, Zabel TH, Donahue DJ, Berger R. 1985. Major revisions in the Pleistocene age assignments for North American human skeletons by $\mathrm{C}-14$ accelerator mass spectrometry: none older than 11,000 C-14 years B.P. American Antiquity 50(1):136-40.

Taylor RE, Haynes CV Jr, Stuiver M. 1996. Clovis and 
Folsom age estimates: stratigraphic context and radiocarbon calibration. Antiquity 70(269):515-25.

Turney CSM, Coope GR, Harkness DD, Lowe JJ, Walker MJC. 2000. Implications for the dating of Wisconsinan (Weichselian) late-glacial events of systematic radiocarbon age differences between terrestrial plant macrofossils from a site in SW Ireland. Quaternary Research 53(1):114-21.

Turney CSM, Bird MI, Fifield LK, Roberts RG, Smith M, Dortch CE, Grun R, Lawson E, Ayliffe LK, Miller GH, Dortch J, Cresswell RG. 2001. Early human occupation at Devil's Lair, southwestern Australia 50,000 years ago. Quaternary Research 55(1):3-13.

Tuross N, Dillehay TD. 1995. The mechanism of organic preservation at Monte Verde, Chile, and one use of biomolecules in archaeological interpretation. Journal of Field Archaeology 22(1):97-110.

Underhill DA, Li J, Zemans R, Oefner PJ, Cavalli-Sforza LL. 1996. A Pre-Columbian Y chromosome-specific transition and its implications for human evolutionary history. Proceedings of the National Academy of Sciences 93:196-200.

Underhill DA, Shen P, Lin AA, Jin L, Passarino G, Yang WH, Kauffman E, Bonne-Tamir B, Bertranpetit J, Francalacci P, Ibrahim M, Jenkins T, Kidd JR, Mehdi SQ, Seielstad MT, Wells RS, Piazza A, Davis RW, Feldman MW, Cavalli-Sforza LL, Oefner PJ. 2000. Y chromosome sequence variation and the history of human populations. Nature Genetics 26(3):358-61.

Vartanyan SL, Arslanov KA, Tertychnaya TV, Chernov SB. 1995. Radiocarbon dating evidence for mammoths on Wrangel Island, Arctic Ocean, until 2000 BC. Radiocarbon 37(1):1-6.

Vasilievsky RS. 1996. Ustinovka 1. In: West FH, editor. American beginnings: the prehistory and palaeoecology of Beringia. Chicago: University of Chicago Press. p 255-67.

Waters MR. 1985. Early man in the New World: an evaluation of the radiocarbon-dated pre-Clovis sites in the Americas. In: Mead JI, Meltzer DJ, editors. Environments and extinctions: man in Late Glacial North America. Orono: Center for the Study of Early Man. p $125-44$.

West FH. 1981. The archaeology of Beringia. New York: Columbia University Press.

West FH, editor. 1996. American beginnings: the prehis- tory and palaeoecology of Beringia. Chicago: University of Chicago Press.

Whitley DS, Dorn RI. 1993. New perspectives on the Clovis vs. pre-Clovis controversy. American Antiquity 58(4):626-47.

Whitridge P. 2001. Zen fish: a consideration of the discordance between artifactual and zooarchaeological indicators of Thule Inuit fish use. Journal of Anthropological Archaeology 20:3-72.

Wilson MC, Burns JA. 1999. Searching for the earliest Canadians: wide corridors, narrow doorways, small windows. In: Bonnichsen R, Turnmire KL, editors. Ice Age people of North America, environments, origins, and adaptations. Corvallis: Oregon State University Press. p 213-48.

Wisner G. 1999. Channel Island woman may be oldest yet. Mammoth Trumpet 14(3):1.

Yesner DR. 1998a. Origins and development of maritime adaptations in the northwest Pacific region of North America: a zooarchaeological perspective. Arctic Anthropology 35(1):204-22.

Yesner DR. 1998b. Colonization models, archaeological signatures, and early sites in interior Alaska. Paper presented at 63rd Annual Meeting of the Society for American Archaeology, Seattle, 26 March.

Yi S, Clark G. 1985. The "Dyuktai Culture" and New World origins. Current Anthropology 26(1): 1-20.

Yu Z. 2000. Ecosystem response to Lateglacial and early Holocene climate oscillations in the Great Lakes region of North America. Quaternary Science Reviews 19:1723-47.

Yu Z, Eicher U. Three amphi-Atlantic century-scale cold events during the Bølling-Allerød warm period. Géographie Physique et Quaternaire. Forthcoming.

Yu Z, Wright HE Jr. 2001. Response of interior North America to abrupt climate oscillations in the North Atlantic region during the last deglaciation. Earth-Science Reviews 52:333-69.

Zdanowicz CM, Zielinski GA, Germani MS. 1999. Mount Mazama eruption: calendrical age verified and atmospheric impact assessed. Geology 27(7):621-4.

Zielinski GA, Mayewski PA, Meeker LD, Whitlow S, Twickler MS. A 110,000-yr record of explosive volcanism from the GISP2 (Greenland) ice core. Quaternary Research 45(2):109-18. 